\title{
PRODUTOS,
}

FORNECEDORES E

ARTESÃOS EM OBRAS

DO ESCRITÓRIO

TÉCNICO SAMUEL

DAS NEVES: 1909-1920

ANA PAULA NASCIMENTO, UNIVERSIDADE DE SÃO PAULO, SÃO PAULO, SÃO PAULO, BRASIL.

Pesquisadora vinculada ao Programa de Pós-graduação da Faculdade de Arquitetura e Urbanismo da

Universidade de São Paulo (FAU-USP). Possui graduação em Arquitetura e Urbanismo (1997), mestrado (2003) e doutorado (2009) em História e Fundamentos da Arquitetura e do Urbanismo pela FAU-USP. Tem experiência nas áreas de História da Arte e História da Arquitetura, com ênfase nos seguintes temas: arte

brasileira (séculos XIX e XX), museus brasileiros, patrimônio e história da arquitetura.

E-mail: ananas1@gmail.com

DOI

http://dx.doi.org/10.11606/issn.1980-4466.v0i23p114-148 


\section{PRODUTOS, FORNECEDORES E ARTESÃOS EM OBRAS DO ESCRITÓRIO TÉCNICO SAMUEL DAS NEVES: 1909-1920 \\ ANA PAULA NASCIMENTO}

\section{RESUMO}

O artigo apresenta — ainda que de maneira sucinta - algumas das empresas importadoras, casas comerciais e prestadores de serviços que atuaram em parte das obras realizadas pelo Escritório Técnico do Engenheiro Samuel das Neves - empreiteiro e contrutor no período entre 1909 e 1920, a partir de notas fiscais e de serviços existentes na documentação desse estúdio de engenharia e arquitetura. Tais documentos estão relacionados com obras de maior porte e de importantes clientes do estabelecimento. Busca-se recuperar, mesmo que em meio a fragmentos, informações sobre tais empresas e lojas, materiais empregados, profissionais atuantes e serviços prestados, visando a ampliar as informações a respeito dos agentes envolvidos em algumas das construções paulistanas do início do século XX. Aborda a questão da formação profissional e da preponderância de imigrantes tanto nas organizações comerciais como nas atividades artesanais oferecidas. Da mesma maneira, apresenta o envolvimento de alguns agentes - notadamente engenheiros - em diversas etapas da cadeia produtiva relacionada à construção civil (empresas para extração de material bruto, casas comerciais, serviços de importação, elaboração de projetos e construções para aluguel).

\section{PALAVRAS-CHAVE}

Arquitetura eclética. Materiais de construção. Estabelecimento comercial. 


\section{PRODUCTS, SUPPLIERS AND CRAFTSMEN IN THE WORKS OF TECHNICAL OFFICE SAMUEL DAS NEVES: 1909-1920 \\ ANA PAULA NASCIMENTO}

\section{ABSTRACT}

This article presents a survey of some of the importing companies, construction materials suppliers and service providers that participated in the works carried out by the Technical Office of Engineer Samuel das Neves —contractor and builder in the period between 1909 and 1920, from the invoices and service contracts from that engineering and architecture office. These documents are related to larger works and important clients. It aims to recover, even in the midst of documentation fragments, information on such companies and professionals working at that time, employed materials and services rendered, aiming at expanding the information about the agents involved in some of the buildings of São Paulo city in the early twentieth century. It addresses the subject of vocational training and the preponderance of immigrants in both commercial organizations and craft activities. In the same way, it presents the involvement of some main actors - notably engineers - in various stages of the production chain (companies for extraction of raw material, suppliers, import services, project design and houses for rent).

\section{KEYWORDS}

Eclectic architecture. Materials suppliers. Building materials. 


\section{INTRODUÇÃO}

Discorrer sobre a história da arquitetura muitas vezes tem como principal escopo os períodos considerados exponenciais, optando-se pelo estudo e análise de obras emblemáticas e narrativa de trajetórias profissionais exemplares. Esse não é um atributo apenas de pesquisas atuais mas é uma das formas mais frequentes de produção de conhecimento na área. Para alguns autores, há diversos estudos e livros; para outros, algumas páginas sobre as atividades mais destacadas, permanecendo a grande maioria desconhecida até mesmo na literatura específica. Costumeiramente, sabe-se o nome dos principais sócios de um determinado escritório. Porém, é muito difícil ocorrer o mesmo com colaboradores, quanto mais com as empresas e os profissionais contratados para a execução de determinadas fases das empreitadas. Busca-se aqui mapear algumas das empresas que trabalharam para o Escritório Técnico do Engenheiro Samuel das Neves, especialmente entre 1909 e 1920, a partir dos vestígios materiais que subsistem no próprio fundo documental do profissional: uma série de notas fiscais e recibos de parte das obras realizadas pelo estabelecimento, documentos estes que foram acidentalmente guardados entre outros tantos, como projetos, memoriais descritivos, contratos e correspondências.

O recorte escolhido faz parte do período de maior produção do engenheiro, ao menos no Estado de São Paulo, mas nem todas as obras são 
aqui referidas, porquanto o conjunto é bastante fragmentado e compreende um número reduzido de projetos face ao todo realizado pelo escritório. Despontam papéis referentes às construções de maior porte, pertencentes a clientes abastados e, igualmente, as de propriedades do próprio engenheiro. ${ }^{1}$ Todavia, tais documentos podem auxiliar no conhecimento mesmo que parcial - dos estabelecimentos contratados pelo escritório, alguns dos produtos utilizados, localização das casas comerciais na cidade, e qualidade do material impresso produzido. Podem ainda trazer pistas sobre tais agentes e a respeito das casas comerciais atuantes no começo do século em São Paulo, assunto até a atualidade muito pouco conhecido.

\section{COLABORADORES E OBRAS}

No Fundo Samuel das Neves, pertencente à Biblioteca da Faculdade de Arquitetura e Urbanismo da Universidade de São Paulo, foram preservadas 476 notas fiscais e 73 recibos referentes a 70 estabelecimentos ${ }^{2}$ ligados à construção civil: empresas importadoras - muitas delas também exportadoras - , lojas de materiais básicos e casas com profissionais volta-

1. Como outros profissionais da área, Samuel das Neves (1863-1937) procurou ao longo da trajetória profissional diversificar suas fontes de renda. Além do escritório de engenharia e construção, participou de sociedades anônimas, redigiu artigos para jornais e revistas e atuou como cônsul da Argentina (1903-c.1905) e do Panamá (1909-1937) em São Paulo. Também construiu residências para aluguel, como os três palacetes em Santa Cecília, sendo um na rua São Vicente de Paula, 9, e os outros dois na rua Albuquerque Lins, 143 e 145, além de uma casa de menor dimensão na rua Prates, no Bom Retiro.

2. Foram organizados documentos dos seguintes estabelecimentos, para os quais tentou-se estabelecer uma organização mínima: Casas de Decoração, Marmorarias, Casas de Pintura: Antonio Moscato - Envernizador; Casa Cabral; Casa Conrado; F. Conti \& Filho - Pintores e Decoradores; Giovanni Rovida Marmoraria; João Pires Armada - Pintor; José Pires Armada - Decorador; Marmoraria da Victoria; Oficina Artístico-Industrial D'Esculptor e Estucador Ulysses Pelliciotti; Oficina de Pintura Luiz Perticarati; Oficina de Pinturas e Reformas - Carmine Ranaldi; Paciullo \& Bonoldi - Grande Oficina de Escultura e Estucador/Paciullo \& Ratto - Oficina de Escultura. Casas Importadoras: A Metralhadora; Bromberg, Hacker \& Cia.; Casa Americana - Augusto Pinto è Cia.; Casa de Importação José Borri; Casa Nathan; Companhia Mecânica e Importadora de São Paulo; Coutinho \& Cia. Importadores; Ernesto de Castro \& Cia.; Favero, Cancer \& Cia.I Th. Cancer \& Co.; Hermann Warnecke \& Cia. (Casa Hermann); Schmidt, Trost \& Co.; Stockler das Neves - Materiais para construção; The Brazilian Forging, Steel Structural \& Importing Co. Lt.; Thomaz, Irmão \& Cia. Importadores. Depósitos/Materiais básicos: A. Lippi e Irmão; Caieira Nacional - Pedra do Sino; Caieiras de Lilyland; Cerâmica Paulista; Companhia Fabricadora de Cal - Cal do Pantojo; Companhia S. Paulo Industrial; Fábrica de tubos de cimento - Raphael Ficondo; Fundição do Braz - F. Amaro; Fundição Modelo e Oficina Mecânica G. Fiorentini; Grande Fundição e Oficinas Mecânicas - Craig \& Martins; J. Penna é Companhia; José Maraston - Fornecedor de areia e pedregulho; Lion \& Co.; Olaria da Minhoca; Olaria Modelo - Waldemar Krisch; Pietro 


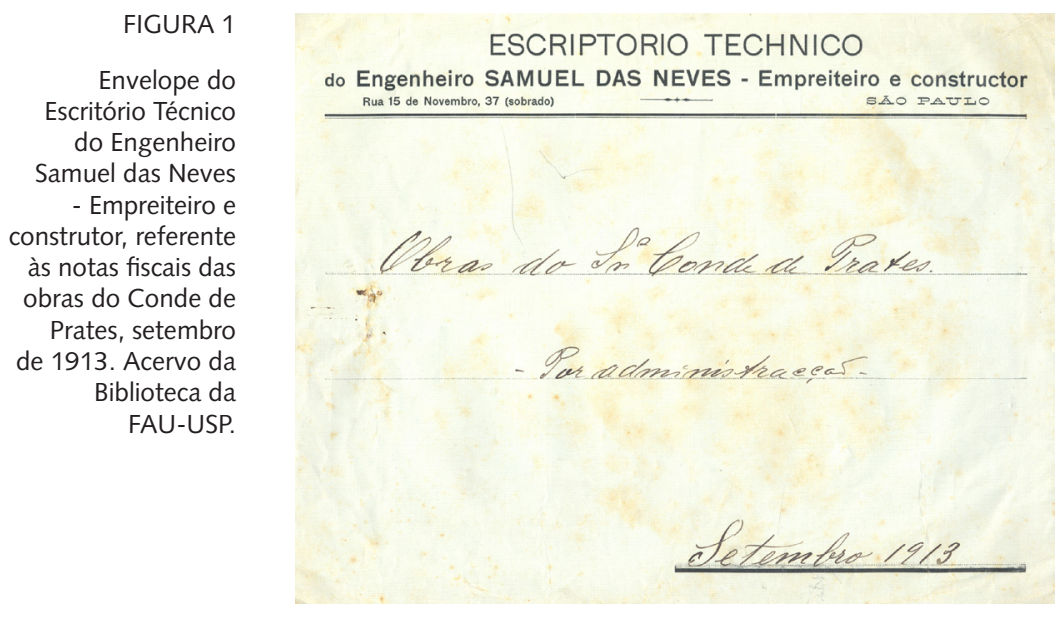

dos às artes aplicadas, que de alguma maneira estiveram envolvidos com uma ou mais obras construídas ou reformadas predominantemente pelo próprio Samuel das Neves entre 1909 e $1920 .^{3}$

Dado o grande conjunto, a diferença de tipologias e o tamanho dos estabelecimentos, até o momento não foi possível localizar informações de muitos deles. Contudo, a organização deste material tem como principais premissas acrescentar informações em vista de estudos futuros mais aprofundados sobre o tema e ampliar o conhecimento sobre alguns dos fornecedores dos escritórios de engenharia, construção e arquitetura do início do século XX.

Angeli - areia; Sacoman Frères; Velloso, Filho \& Cia. Instalações Hidráulicas e Elétricas: Casa D’Orsi - encanamento e eletricidade - Paschoal D’Orsi \& Filho; Casa da Bóia - Rizkallah Jorge; Casa Fabbri - Hildebrando Fabbri; Oficina do Vesúvio - José Rivello; Oficina Hidráulica e Funilaria João Descagni. Ladrilhos Hidráulicos: Casa Helvetia - Fábrica de Ladrilhos de Cimento; Fábrica Ítalo Brasileira de Mosaicos e Ladrilhos em Cimento; J. Zaragoza \& Comp. - Cooperativa - Fábrica de Ladrilhos e Mosaicos. Marcenaria e Carpintaria: Carpintaria Confiança; Envernizador de Madeira João Biz; João Favaron - Raspador de soalhos; Joaquim Cardoso \& Cia. - Oficina de Carpinteiro e Marceneiro; Marcenaria e Carpintaria Ítalo-Americana - Pedro Sellaro; Oficina de Carpintaria e Marcenaria de José Checchia. Serraria e Serralherias: Giovannetti \& Irmão - Grande Oficina de Serralheiros e Ferreiros; Oficina Mecânica e Serralheria Piratininga - Milton Giancoli; Serraria "Bella Vista" - Ernesto Amadei; Serraria 15 de Novembro - Jorge Silveira \& C.; Serraria Barra Funda; Serraria Carvalho - Diogo José de Carvalho; Serraria e Serralheria Santa Lucia; Serraria São Carlos - Krug \& Co.

3. A maioria dos documentos conservados compreende o período entre 1912 e 1915, quando o filho de Samuel e arquiteto Christiano Stockler das Neves (1889-1992) trabalhava no escritório mas ainda não era sócio da firma. As informações sobre a sociedade entre pai e filho passam a circular na imprensa a partir de 1915, o que parece acentuar a predominância de Samuel das Neves na obtenção de encomendas e negociações tanto com particulares como com agentes públicos - a despeito da ampliação do papel de Christiano em relação à linha projetual do estúdio. 
Tabela 1 - Obras realizadas pelo Escritório Técnico Samuel das Neves, das quais foram localizadas notas fiscais com informações sobre as casas de comércio

\begin{tabular}{|c|c|c|c|c|c|}
\hline Ano(s) & Obra & Proprietários & Endereço & Bairro & $\begin{array}{l}\text { Casas } \\
\text { fornecedoras }\end{array}$ \\
\hline 1909 & Residências & $\begin{array}{l}\text { São Paulo Gas } \\
\text { Company Ltda. }\end{array}$ & $\begin{array}{l}\text { avenida Rangel } \\
\text { Pestana com rua } \\
\text { Santa Cruz da } \\
\text { Figueira }\end{array}$ & Brás & $+* D$ \\
\hline $\begin{array}{l}1912 \\
1913\end{array}$ & $\begin{array}{l}\text { Obras não } \\
\text { identificadas }\end{array}$ & Conde de Prates & & Centro & $\bullet *$ \\
\hline $\begin{array}{l}1912 \\
1913 \\
1914 \\
1915\end{array}$ & Casa Michel & $\begin{array}{l}\text { Michel Worms \& } \\
\text { Irmãos }\end{array}$ & $\begin{array}{l}\text { rua XV de } \\
\text { Novembro, 25-27 } \\
\text { com Rua da } \\
\text { Quitanda }\end{array}$ & Centro & 紊 \\
\hline $\begin{array}{l}1912 \\
1913\end{array}$ & Residência & & $\begin{array}{l}\text { rua Albuquerque Lins } \\
\text { com rua Baronesa de } \\
\text { Itu }\end{array}$ & Santa Cecília & $\bullet \bullet * \square \diamond$ \\
\hline 1913 & $\begin{array}{l}\text { Obras no Vale } \\
\text { do } \\
\text { Anhangabaú }\end{array}$ & $\begin{array}{l}\text { [possivelmente } \\
\text { do Conde de } \\
\text { Prates] }\end{array}$ & & Centro & $\Leftrightarrow$ \\
\hline 1913 & $\begin{array}{l}\text { Edifício } \\
\text { comercial }\end{array}$ & $\begin{array}{l}\text { Rodrigo } \\
\text { Monteiro } \\
\text { Junqueira }\end{array}$ & $\begin{array}{l}\text { rua dos Andradas, } \\
38-44\end{array}$ & Santa Ifigênia & $\square$ \\
\hline 1913 & & $\begin{array}{l}\text { [possivelmente } \\
\text { do Conde de } \\
\text { Prates] }\end{array}$ & rua Formosa & Centro & 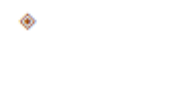 \\
\hline 1913 & & & $\begin{array}{l}\text { rua Libero Badaró, } \\
27\end{array}$ & Centro & 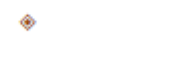 \\
\hline $\begin{array}{l}1913 \\
1914 \\
1915\end{array}$ & $\begin{array}{l}\text { Dois palacetes } \\
\text { construídos } \\
\text { para aluguel }\end{array}$ & $\begin{array}{l}\text { Samuel das } \\
\text { Neves }\end{array}$ & $\begin{array}{l}\text { rua Albuquerque } \\
\text { Lins, } 143-145\end{array}$ & Santa Cecilia & $\square$ \\
\hline $\begin{array}{l}1913 \\
1914\end{array}$ & $\begin{array}{l}\text { Palacete } \\
\text { Prates / } \\
\text { Automóvel } \\
\text { Clube }\end{array}$ & Conde de Prates & $\begin{array}{l}\text { rua Libero Badaró, } \\
25,27,29 \text { e } 31\end{array}$ & Centro & •*ロ・ \\
\hline $\begin{array}{l}1913 \\
1914 \\
1915\end{array}$ & Edifício & & rua Direita, 57 & Centro & $* * \times \square+*$ \\
\hline 1914 & $\begin{array}{l}\text { Edifício } \\
\text { comercial }\end{array}$ & $\begin{array}{l}\text { Domingos de } \\
\text { Paiva Azevedo }\end{array}$ & $\begin{array}{l}\text { rua e Ladeira do } \\
\text { Carmo }\end{array}$ & Sé & $* * \bullet \cdot \times \bullet *$ \\
\hline 1914 & Edifício & Conde de Prates & $\begin{array}{l}\text { rua Libero Badaró, } \\
40-42\end{array}$ & Centro & - \\
\hline 1914 & Residência & $\begin{array}{l}\text { José de } \\
\text { Sampaio } \\
\text { Moreira }\end{array}$ & rua Fausto Ferraz, 9 & Bela Vista & ** $* \times \square$ * \\
\hline 1914 & Palacete & $\begin{array}{l}\text { Sampaio } \\
\text { Moreira }\end{array}$ & $\begin{array}{l}\text { rua Albuquerque } \\
\text { Lins, } 110 \text { com } \\
\text { Alameda Barros }\end{array}$ & Santa Cecília & $* * \circ *$ \\
\hline
\end{tabular}


Tabela 1 - Obras realizadas pelo Escritório Técnico Samuel das Neves, das quais foram localizadas notas fiscais com informações sobre as casas de comércio

\begin{tabular}{|c|c|c|c|c|c|}
\hline Ano(s) & Obra & Proprietários & Endereço & Bairro & $\begin{array}{l}\text { Casas } \\
\text { fornecedoras }\end{array}$ \\
\hline $\begin{array}{l}1914 \\
1915\end{array}$ & & $\begin{array}{l}\text { [Família } \\
\text { Campos] }\end{array}$ & $\begin{array}{l}\text { rua Libero Badaró, } \\
84-86\end{array}$ & Centro & $* \bullet \times+\square+*$ \\
\hline 1915 & & & rua Pernambuco, 6 & Higienópolis & * \\
\hline 1915 & & & $\begin{array}{l}\text { rua XV de } \\
\text { Novembro, } 58\end{array}$ & Centro & * \\
\hline 1920 & $\begin{array}{l}\text { Chácara do } \\
\text { Carvalho } \\
\text { [reforma] }\end{array}$ & $\begin{array}{l}\text { Antônio da Silva } \\
\text { Prado }\end{array}$ & $\begin{array}{l}\text { Alameda Barão de } \\
\text { Limeira }\end{array}$ & Barra Funda & + \\
\hline
\end{tabular}

TABELA 1 - Casas fornecedoras e respectivas obras: 1 - Bromberg, Hacker \& Cia. [t]; 2 - Casa Cabral [•]; 3 - Casa Conrado [*]; 4 - Casa da Bóia [४]; 5 - Casa Helvetia [○]; 6 - Casa Hermann [ $[$ ]; 7 - Coutinho \& Cia. [*]; 8 - Ernesto de Castro \& Cia. [*]; 9 - Fundição do Braz [※]; 10 - Grande Fundição e Oficinas Mecânicas - Craig \& Martins [•]; 11 - Marcenaria e Carpintaria Italo-Americana - Pedro Sellaro [:]; 12 - Officina Artístico-Industrial D'Escultor e Estucador Ulysses Pellicciotti [*]; 13 - Paciullo \& Bonoldi - Grande Officina de Esculptura e Estucador [X]; 14 - Paciullo \& Ratto Officina de Esculptura [+]; 15 - Sacoman Frères - Estabelecimento cerâmico [+]; 16 - Schmidt, Trost \& Cia. [*]; 17 - Serraria Bella Vista [*]; 18 - Serraria e Serralheria Santa Lucia [•]; 19 - Serraria São Carlos - Krug \& Cia. [ D]; 20 - Stockler das Neves \& Cia. [-]; 21 -The Brazilian Forging, Steel Structural \& Importing Co. Ltd. [•].

As informações sobre essas firmas são imprecisas e lacunares. As empresas surgem e desaparecem sem deixar registro, e muitas vezes mesmo as informações localizadas a respeito destes estabelecimentos são pouco elucidativas, contando apenas com os respectivos endereços, produtos vendidos e serviços ofertados. A seguir, serão tratados os estabelecimentos dos quais foi possível obter informações, organizados por categorias não tão claras e que muitas vezes se interpenetram.

\subsection{Casas importadoras}

A ampliação das exportações de café, o enriquecimento dos fazendeiros paulistas e, consequentemente, a mudança do status do Estado de São Paulo em relação ao país, ampliaram consideravelmente o comércio de artigos de luxo para as residências abastadas ao menos a partir da última década do século XIX. Se os vagões da ferrovia Santos-Jundiaí seguiam para o litoral com o "ouro vermelho", subiam a Serra do Mar com cha- 
pas galvanizadas de Flandres, pinho de Riga, vidros coloridos da Bélgica, mármore de Carrara, telhas e cerâmicas de Marselha, ferragens e louças sanitárias inglesas, cristais da Boêmia, além de papéis de parede, móveis e toda a sorte de ferragens e objetos decorativos; enfim, muitos dos objetos importantes naquele período para reproduzir os padrões de residência europeus e estarem estas casas à altura de serem reproduzidas nas revistas nacionais lidas por tal camada social.

Em um primeiro momento do surto construtivo na cidade, temos a impressão de que apenas materiais básicos eram produzidos in loco - areia, pedra, cal e tijolo. Todos os outros componentes de um memorial descritivo pareciam ter atravessado o oceano. Portanto, concluído o arcabouço de paredes de uma residência, ela era coberta e ornamentada com toda a sorte de produtos da indústria europeia. Com esses novos processos, São Paulo conheceu novos tipos de habitação, nos estilos arquitetônicos e técnicas construtivas, em grande parte devido à importação de materiais e de modelos e, igualmente, à atuação de novos agentes sociais: os imigrantes e descendentes, muitos com formação profissional adquirida na terra natal, outros aqui formados.

Todavia, vale a pena ressaltar que o sistema de importações foi fundamental à industrialização de São Paulo porque, ao contrário de boicotar a iniciativa local, tal processo funcionou como rede de fornecimento de vários produtos necessários à implementação e ao próprio movimento industrial do país (BARBUY, 2006, p. 165). Com isso, houve a ampliação da produção e o incremento da indústria da construção civil em relação às importações, especialmente a partir da I Guerra Mundial, quando as relações comerciais internacionais foram praticamente interrompidas. Como resultado, muitas das casas comerciais que importavam produtos sofisticados ao mesmo tempo produziam materiais mais simples e de grande consumo para obras diversas, em um sistema misto e em constante adaptação ao mercado local.

Além das casas importadoras, havia ainda a atuação do importador direto, especialmente no caso de estruturas metálicas, porquanto as empresas nacionais, apesar dos avanços técnicos, ainda não eram capazes de produzir estruturas completas, fazendo apenas pilares, vigas e postes em ferro fundido. Acrescente-se o fato de o ferro para as obras igualmente ser 
importado, principalmente da Inglaterra, dos Estados Unidos e da Alemanha. Por isso, é usual nas plantas do período, nas primeiras tentativas de verticalização da cidade, predominantemente com o uso de estruturas metálicas, a existência de carimbos da Anglo-Brazilian Forging Steel Structural and Importing Co. Ltd. ou da Vaughan \& Dymond Engineers da Inglaterra, como aparecem nas plantas dos palacetes do Conde de Prates (1860-1928). $\mathrm{O}$ processo era bastante oneroso porque, além da importação de toda a estrutura, era necessária a vinda de técnicos para a montagem.

Algumas empresas de grande porte passaram a atuar na cidade com o crescimento econômico e as eminentes oportunidades. A Bromberg, $\mathrm{Ha}$ cker \& Cia. foi uma delas. Sediada em Hamburgo, era uma das maiores e mais conhecidas casas importadoras alemãs na cidade. Contava também com filiais no Rio de Janeiro, em Porto Alegre, no Rio Grande, em Pelotas e em Buenos Aires, pois muitos dos seus negócios assentavam-se no sul do país e em terras vizinhas. Com ampla experiência na área da mecânica, realizava diversos tipos de instalações industriais, em diferentes pontos do país: usinas elétricas e hidráulicas, fábricas de fiação e de papel, cervejarias, olarias, engenhos de açúcar e de arroz, tipografias, elevadores elétricos, guindastes, instalações telegráficas e telefônicas. Em São Paulo, o ponto de comercialização situava-se no centro, à rua da Quitanda, 10, e os depósitos da firma, nas proximidades da Estação Central da São Paulo Railway, no Brás. Além dos serviços oferecidos, vendiam grande sortimento de produtos importados para a indústria e para o varejo, como máquinas, aparelhos e material elétrico. Também representavam diversas outras empresas alemãs no país (IMPRESSÕES, 1913).

Outra empresa atuante no ramo era a Coutinho \& Cia., cujo endereço era a rua José Bonifácio, 28. O principal foco era a importação e o comércio de máquinas para a lavoura, ferragens, maquinismos, utensílios agrícolas e industriais, tubos de ferro galvanizado, conexões, encerados, lonas, arames farpados, telhas de zinco, entre outros materiais, como as folhas de ouro fornecidas para a Chácara do Carvalho.

A Ernesto de Castro \& Cia., casa fundada em 1889, inicialmente sob a razão social de Azevedo, Bueno \& Cia., passou mais tarde a ser denominada E. P. Bueno \& Cia. e, apenas em 1903, organizou-se como Ernesto de Castro \& Cia. Foi uma das maiores fornecedoras para as obras do Escritó- 
rio Técnico Ramos de Azevedo, tendo o próprio engenheiro Francisco de Paula Ramos de Azevedo (1851-1928) ${ }^{4}$ como sócio majoritário e Ernesto Dias de Castro (1873-1955) - genro de Ramos de Azevedo e engenheiro civil -, e Mario Dias de Castro, como sócios-solidários.

Por um período, foi a maior e mais sortida casa importadora da cidade. Importava em grande escala todos os artigos necessários para construção de edifícios, como ferragens, tintas, vigas de ferro, cerâmica, artigos sanitários, aparelhos para gás e eletricidade, tubos para água, óleos, cimento, madeiras, e também maquinismos para lavoura, indústrias e estradas de ferro. Possuía ainda a Serraria Central - Azevedo Miranda \& Cia., utilizando madeiras de lei e pinho nacional, pinho de resina importado da América do Norte e pinho da Suécia. O armazém e escritório ocupavam vasto prédio de quatro pavimentos no centro da cidade, à rua Boa Vista, 26, no mesmo edifício em que funcionava o Escritório Técnico F. P. Ramos de Azevedo; e o depósito era na rua Visconde de Parnaíba, 220, no Brás, em área de cerca de $30.000 \mathrm{~m}^{2}$, possuindo um desvio duplo da São Paulo Railway.

Dada a dimensão do empreendimento, a empresa responsabilizavase também pela distribuição das mercadorias, realizada inicialmente por carroças e, posteriormente, por caminhões (IMPRESSÕES, 1913), o que demonstra um grande volume de vendas para o período.

Também operava na área a Schmidt, Trost \& Cia. Com a primitiva razão de Schmidt \& Trost, a empresa fora fundada em 1890 e, a partir de 1910, passou a ter a segunda denominação. Atuava com importação de materiais de construção e também exportação de café, que era produzido em fazenda da empresa no interior do Estado. Concomitantemente, trabalhava com linhas de navegação e companhias de seguros, diversificando ao máximo os tipos de negócios. Na seção de importação, o forte eram as ferragens, incluindo ferro bruto, aço, arame, metais, outros

\footnotetext{
4. Possivelmente, foi Ramos de Azevedo um dos primeiros profissionais ligados à arquitetura, engenharia e construção a ter negócios paralelos ao funcionamento do escritório, ao menos no Estado de São Paulo. Associou-se a Joaquim Monteiro de Carvalho na exploração de madeiras no Estado do Paraná. Na fazenda Itapararanga, imediações da atual cidade de Votorantim, explorou cal, mármore e granitos variados. Foi o proprietário da Cerâmica Vila Prudente. Em 1916, comprou um sítio nas imediações de Inhaíba para extração de materiais de construção. Também colaborou no Banco União de São Paulo, construiu casas à prestação e loteou bairros, além de exercer atividades didáticas. Para mais informações, consultar Carlos Lemos, Ramos de Azevedo e seu escritório.
} 
FIGURA 2

Empena cega do edifício que abrigava o Escritório Técnico F.

P. Ramos de Azevedo

e o armazém da Ernesto de Castro \& Cia. Também fazem parte do anúncio

a Serraria Central e a Cerâmica Vila Prudente, c. 1924

Coleção particular São Paulo.

FIGURA 3 Nota fiscal da Ernesto de Castro \& Cia. referente a produtos para o Palacete Sampaio Moreira, 1914. Acervo da Biblioteca da FAU-USP.
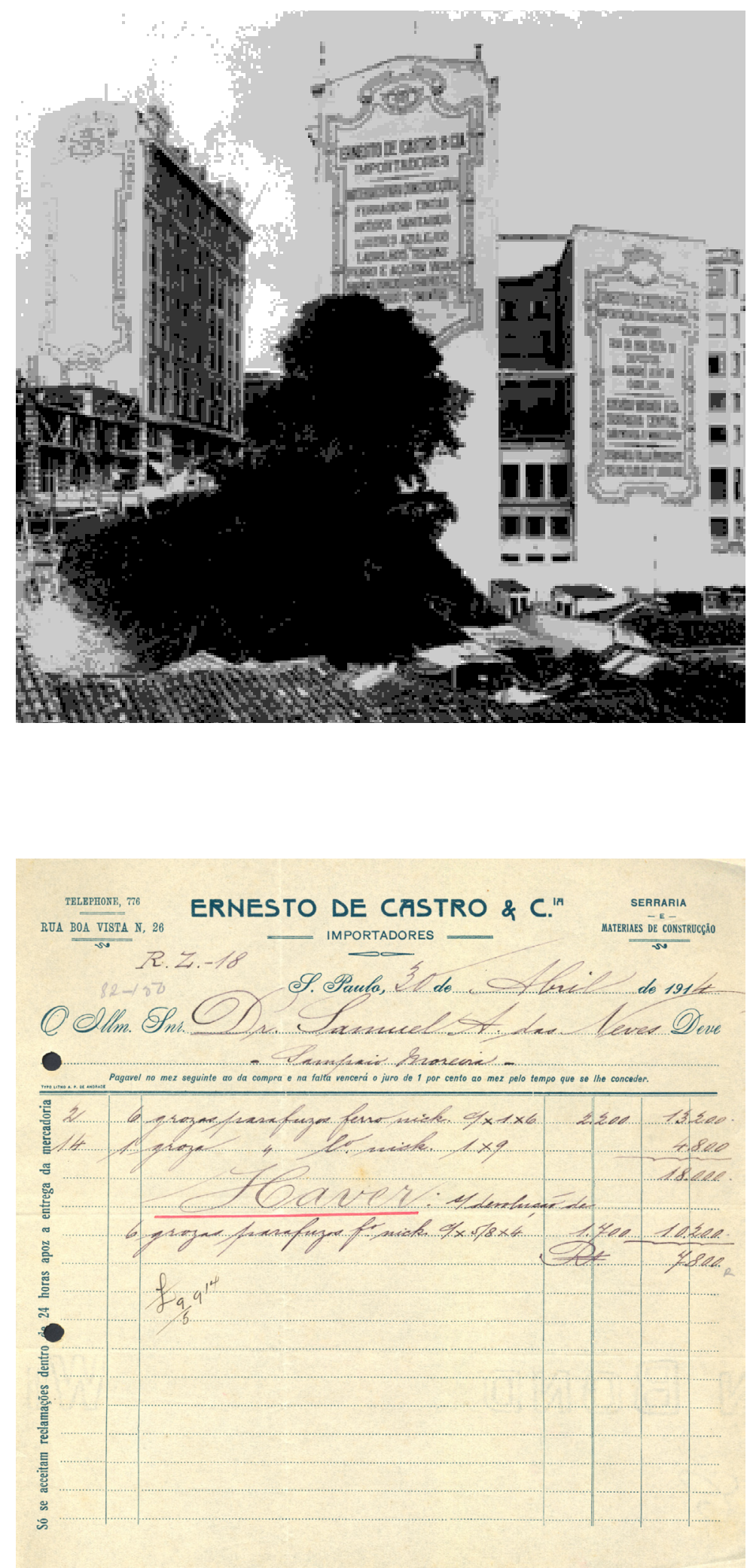

Rev. CPC, São Paulo, n. 23, p. 114-148, jan./jul. 2017. 
materiais para construção, ferramentas de toda a espécie, óleos, tintas e vernizes. O escritório situava-se à rua Álvares Penteado, 9-A, e os depósitos, à rua Domingos Paiva, 40 a 46, no Brás. Possuíam ainda casa para compra de produtos em Hamburgo, sob o nome de Herr Carl Schmidt. Atuavam, outrossim, como agentes de outras empresas, tal como a Bromberg, Hacker \& Cia. Além da firma em São Paulo, mantiveram filial em Santos (IMPRESSÕES, 1913). Para Samuel das Neves, foram vendidos cimento Heidelberg, chapas de metal deployé, feixes de ferro, cimento da Germânia, azulejos hexagonais e azulejos brancos e frisos da cor verde para diversas obras.

Como prática comum de muitos profissionais ligados à construção no período, Samuel das Neves também importou diretamente muitos materiais, como pode ser rastreado a partir das listagens de importações publicadas pelo jornal O Estado de S. Paulo: em 1909, ladrilhos de Marselha, lampiões de Hamburgo, ladrilhos de Antuérpia, louças de Liverpool; no ano seguinte, novamente artigos sanitários de Liverpool e ladrilhos de Havre.

Ao que tudo indica, Augusto Stockler das Neves, filho de Samuel das Neves, bacharel em Direito pela Faculdade do Largo São Francisco e figura importante no Escritório Técnico até pelo menos 1914, fundou a importadora Stockler das Neves \& Comp. por volta de 1911 - período em que o Escritório Técnico possuía grande número de encomendas, notadamente o projeto Melhoramentos de São Paulo e as obras para o Conde de Prates. A empresa, um espécie de depósito, vendia materiais importados e também congêneres nacionais, com endereço em São Paulo - sempre no mesmo edifício do escritório paterno - e filial em Santos.

Como era de esperar, forneceu muitos produtos para as obras do escritório, principalmente para as de Domingos de Paiva Azevedo, José de Sampaio Moreira (1865-1943) e Conde de Prates: ladrilhos cerâmicos, pregos, metal deployé, parquete, cimento, ladrilhos estrangeiros, cimento, azulejo branco, portas de pinho, azulejos e lavatórios. 


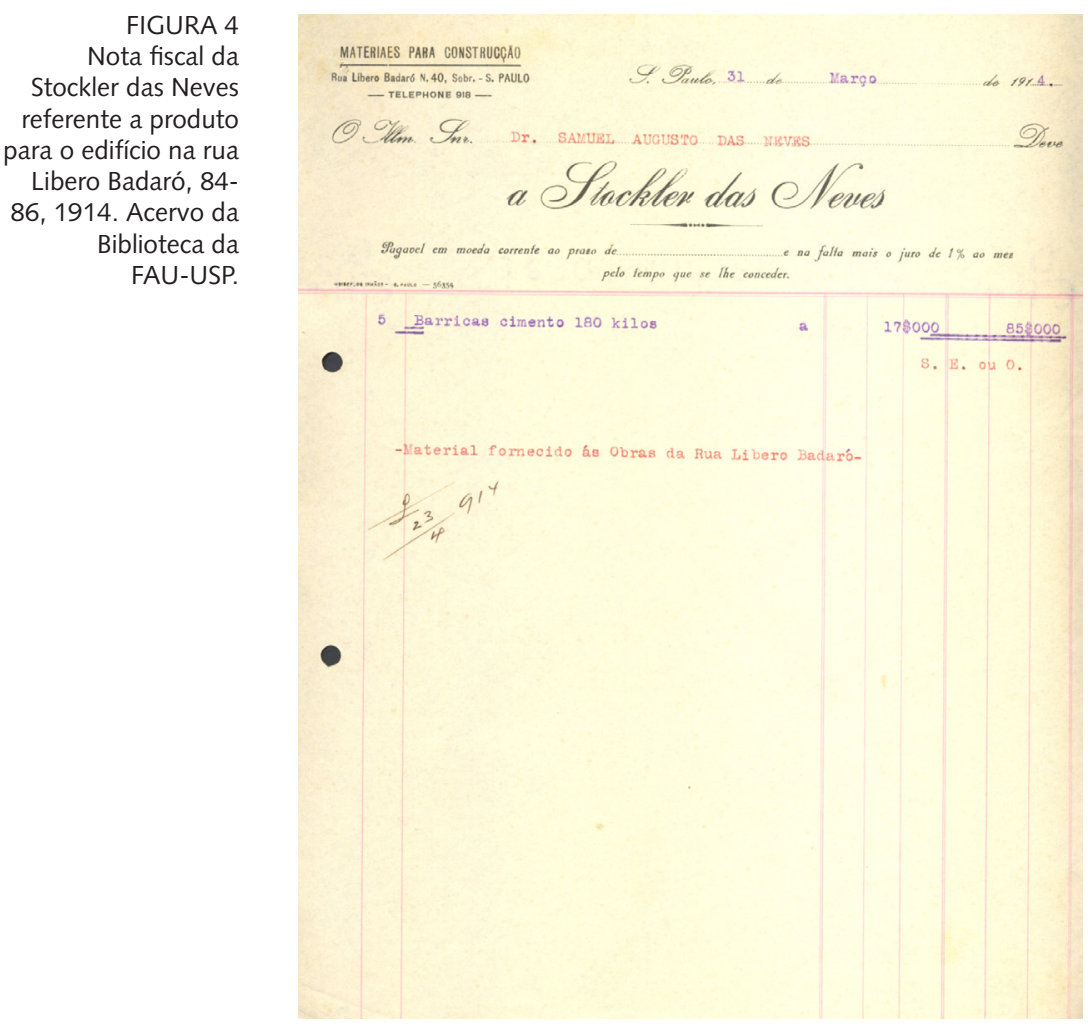

\subsection{Ornatos e decorações}

Desde o final do século XIX, São Paulo passa a possuir escolas profissionais que tinham como principal função formar mão de obra para o segmento da construção civil, em grande expansão. A mais conhecida, completa e importante foi, sem sombra de dúvida, o Liceu de Artes e Ofícios de São Paulo, capitaneada por Ramos de Azevedo. Também devem ser destacadas a Escola Profissional Masculina do Brás e a Escola de Aprendizes e Artífices, a última iniciativa federal.

Para a cidade dos tijolos e arquitetura de forma generalizada denominada "eclética", eram imprescindíveis ornatos para fachadas, pedestais, pilastras, molduras, frisos, capitéis, cornijas, abóbadas, cúpulas, vidros coloridos, papéis de parede, folhas de ouro, estátuas, mármores em cores diversas, pedras artificiais.

Em vista disso, era imenso o repertório de elementos acrescidos aos interiores e às fachadas das construções. Uma regra quase geral era de que 
quanto mais eminente e endinheirado o proprietário, mais ilustre e única deveria ser a ornamentação e a decoração do imóvel. Para satisfazer esse "horror ao vazio" e realizar obras em consonância com o que era esperado para cada camada social existiam, além do Liceu, das outras escolas supracitadas e das casas importadoras, diversos estabelecimentos dedicados à decoração, a maioria localizada no Centro, em Santa Cecília, na Bela Vista, existindo outrossim alguns estabelecimentos no Brás.

Formavam relevantes núcleos de formação profissional, tão necessários para o ramo da construção naquele período, muito procurados como opção de trabalho por garotos com idade a partir dos 14 anos, pois ao mesmo tempo em que aprendiam uma profissão, auxiliavam na subsistência familiar. Tais estabelecimentos surgiram na cidade no final do século XIX, em um primeiro momento apenas para comercializar produtos variados para a construção e adorno das obras: elementos em cerâmica e cimento, entalhes em mármore ou materiais artificiais que imitavam pedras mais raras. Também ofereciam peças em ferro batido, esquadrias e outros produtos. No início do século XX, em muitos deles passaram a funcionar pequenas oficinas nos fundos das lojas, as quais executavam - a partir de encomendas - projetos para decoração de casas e edifícios, empregando desenhistas e artesãos especializados, muitos já formados pelas escolas profissionais então existentes ou imigrantes instruídos no Velho Continente.

Contribuíam como modelo para os produtos livros, revistas e catálogos importados, que eram avidamente manuseados para encomendas diretas ou emulação pelas empresas nacionais. Por conseguinte, buscavase dar às construções um aspecto marcante e individualizado, a partir do uso de muitos elementos compostos.

Dessa maneira, ao menos durante o período da República Velha (1889-1930), o papel dos elementos de ornamentação na arquitetura foi fundamental e os profissionais relacionados com tais atividades, imprescindíveis para a boa finalização das obras. Se de um lado há um grande interesse pelas importações, é crescente o número de estabelecimentos criados para suprir a demanda interna, quer a partir do ensino, quer da prática profissional.

Algumas casas de decoração, ao lado das atividades comerciais, também ofereciam outros atrativos, como pequenas exposições. Podem 
ser citadas como exemplos a Casa Verde, na rua São Bento, 56 - misto de oficina de tapeçaria, ornamentação e artigos de decoração - e a Casa Cabral, a última fundada em 1894, situada na mesma rua, no número 35B.

A Casa Cabral - especializada em vidros, papéis pintados para forros, estampas em geral, espelhos e molduras para quadros, além de telhas de vidro e diamantes de corte - sediou algumas pequenas exposições em suas vitrines: em 1902, exibiu duas pinturas de Oscar Pereira da Silva; em 1909, cópias de quadros dos mestres europeus pertencentes a uma coleção particular (NASCIMENTO, 2009, p. 115, 141); e, em outubro de 1916, expôs louças - ou seja, também funcionava como casa importadora (EXPOSIÇÃO, 1916, p. 4). Pelo exemplo acima, percebe-se que muitas lojas e casas prestadoras de serviços dedicavam-se a diversas frentes na busca por clientes, oferecimento de serviços diferenciados e introdução de novos hábitos. Forneceu papéis de parede para algumas das obras realizadas pelo escritório de Samuel das Neves.

FIGURA 5

Nota fiscal da Casa Cabral referente a produtos para obra na rua Libero Badaró,

40 , e na rua do

Carmo, 1914. Acervo da Biblioteca da FAU-USP.

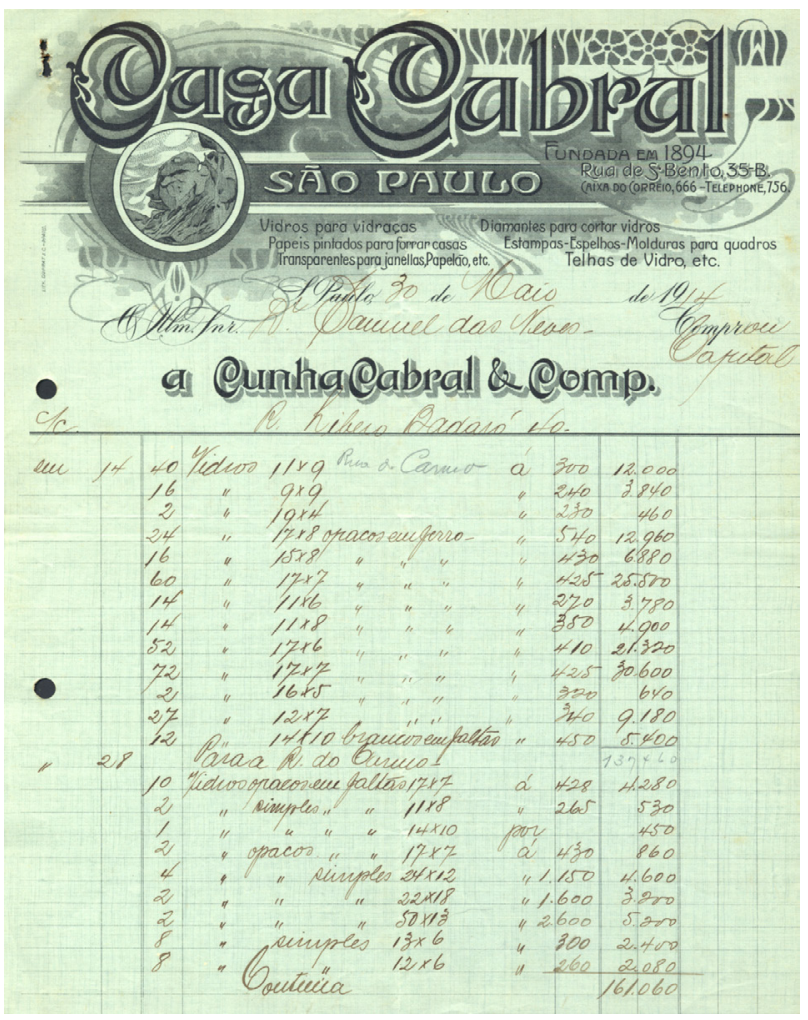


Desta tipologia de estabelecimento, a que até hoje é mais conhecida, principalmente pelo número de obras ainda existentes na cidade, é a Casa Conrado. Arte e Indústria, eis o lema do estabelecimento, fundado em São Paulo em 1889 por Conrado Sorgenicht (1835-1901), imigrante vindo da Renânia católica (atual Alemanha), em 1874. Inicialmente, Sorgenicht abrira uma pequena oficina que disponibilizava serviços de decoração em geral, como pintura de ornamentos e de letreiros, tapeçarias, trabalhos com mármores e madeira; também oferecia colocação de vidros e, posteriormente, criação de vitrais, marca registrada e atividade pela qual a empresa é renomada até a atualidade.

Em um primeiro momento, instalou-se na rua Brigadeiro Tobias, 5 , na República. Depois, transferiu-se para a rua do Triunfo, $10^{5}$, onde funcionará a primeira fábrica - reformada em 1908 pelo Escritório de Samuel das Neves (MELLO, 1996, p. 12, 23-24, 27). A Casa Conrado era especializada em vidros pintados, gravados e decorados. Sorgenicht, por dominar a técnica de vitrais, era praticamente o principal fornecedor de tal categoria. Importava filetes de chumbo e vidros coloridos de diversas regiões da Europa. Foi responsável por inúmeros vitrais em São Paulo, sacros ou não, destacando-se, entre outros, os realizados para a Igreja de Santa Cecília e para o Teatro Municipal. Para obras de Samuel das Neves, forneceu apenas vidros, não tendo sido até o momento localizado nenhum vitral para o escritório.

A empresa participou de diversas exposições industriais, nacionais e universais, tendo sido premiada inúmeras vezes: na Exposição de Saint Louis (1904) - medalha de bronze; Exposição Preparatória SP (1907); grande prêmio na Exposição Nacional (1908); Exposição de Roma (1911) — medalha de ouro; Exposição Universal de Turim (1911) - medalha de prata; Exposição Municipal SP (1918). A participação e, especialmente, a obtenção de prêmios (mesmo que estes fossem distribuídos à larga entre os participantes) configuravam-se estratégias para ampliar os negócios e, de alguma maneira, explicitar aos clientes o grau de avanço do empreendimento, ao figurar lado a lado com congêneres internacionais e ainda receberem distinções.

5. Segundo herdeiros, a fábrica estava situada no Belenzinho mas até o presente não foi possível confirmar a informação. 
FIGURA 6

Nota fiscal da Casa Conrado referente a produtos para residência à rua Fausto Ferraz, 9 1914. Acervo da Biblioteca da FAU-USP.

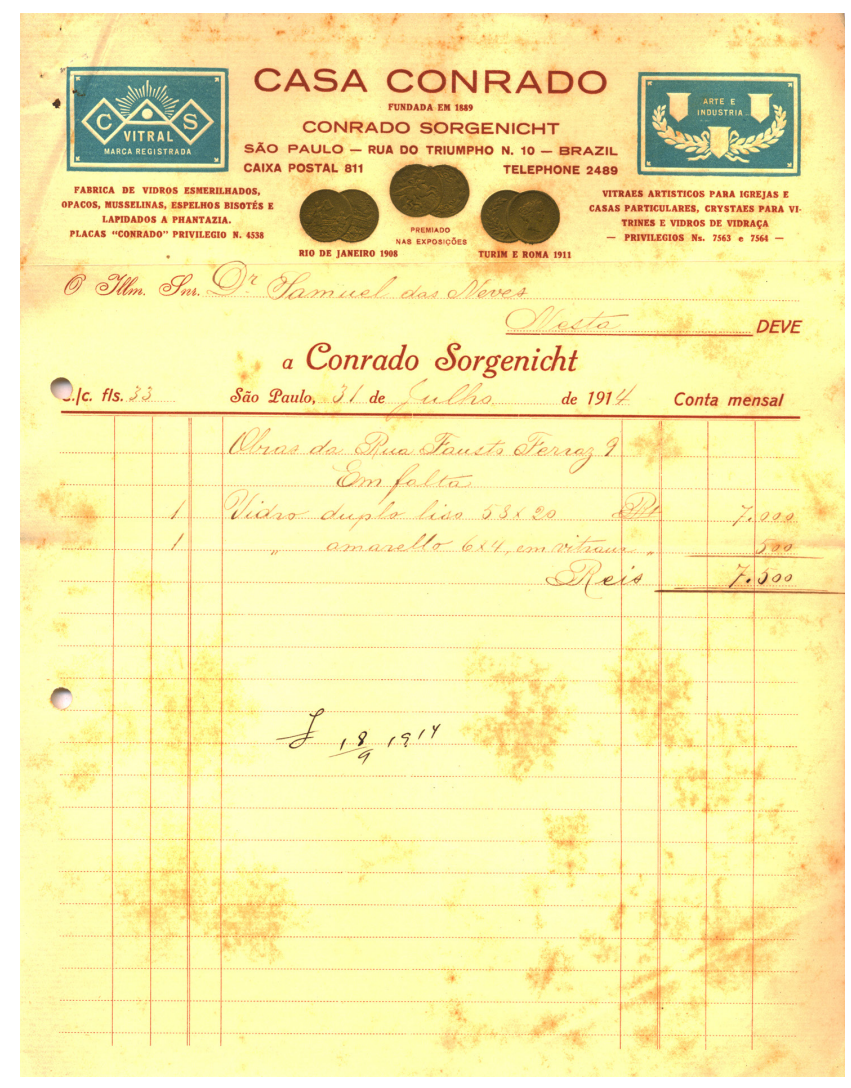

A Casa Helvetia foi outro estabelecimento de grande importância no período. Fundada em 1891 por Achilles Isella, Oreste Isella e Luís Isella, quando do afastamento dos negócios por parte de Oreste, em 1895, e falecimento de Luís, em 1900, passou a ter como único proprietário Achilles. Naquela época, também era conhecida como Casa Helvetia - Fábrica de Ladrilhos de Cimento. Situava-se na atual Avenida Rio Branco, 43. Apesar de funcionar especialmente como oficina de estucador ${ }^{6}$, possuía armazém e importava materiais para construção, entre os quais telhas francesas, cimentos da marca Germânia e outras, gesso de Paris, cimento de presa rápida, telhas de vidro, ladrilhos de Marselha, azulejos. Também comercializava telhas nacionais.

6. Estucador era o profissional que modelava na argila um projeto de ornamento de sua autoria ou que lhe fosse encomendado ou ainda cópia a partir de alguma publicação estrangeira (MACAMBIRA, 1985, p. 38) 
Além das atividades descritas, a Casa Helvetia possuía uma fábrica de ladrilhos na rua Dr. Pedro Vicente, no Canindé, na qual produzia cimento, mosaicos, pedras artificiais, ornamentos e modelos prontos para decoração. Os produtos fabricados eram comercializados principalmente nos estados de São Paulo, Minas Gerais, Rio de Janeiro e Paraná. Entre outras obras, a empresa foi responsável pelos forros do Teatro Municipal de São Paulo, atuando igualmente em muitas obras particulares, como as do Escritório Técnico de Samuel das Neves.

A Casa Helvetia, como outras empresas da mesma área de atuação, participou da Exposição Preparatória SP (1907), da Exposição Universal de Turim (1911) e da Exposição Municipal SP (1918) (BELLUZZO, 1988, p. 487). Contudo, não foram localizadas informações a respeito de prêmios.

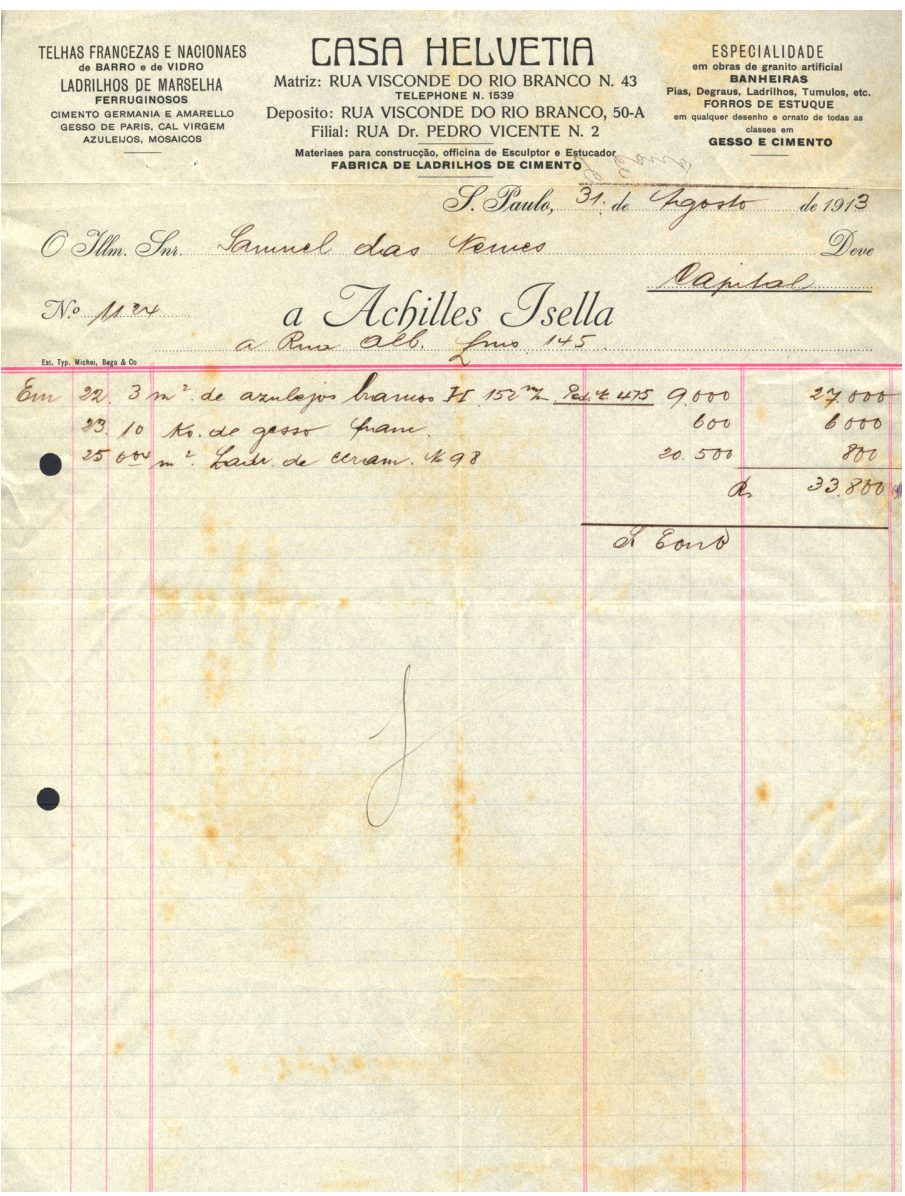


Uma das empresas do ramo com maior longevidade foi a Officina Artístico-Industrial D'Escultor e Estucador Ulysses Pellicciotti. Segundo Macambira (1995, p. 29), foi pioneira entre as lojas de ornamentação na cidade, fundada na primeira década do século XX. Estava situada na avenida Brigadeiro Luiz Antonio, 50, e na rua Francisca Miquelina, 17 - próxima à Praça da Sé, local de concentração de mão de obra especializada em decorações. Era famosa pelos produtos fornecidos e pelos profissionais que lá atuaram, executando obras arquitetônicas e ornamentais nos estilos desejados pelos clientes.

Ulysses Pellicciotti era italiano e estudou em Roma a arte de modelar. Chegando à cidade de São Paulo em 1894, na primeira década do século XX consegue fundar sua loja, uma das maiores e mais conhecidas

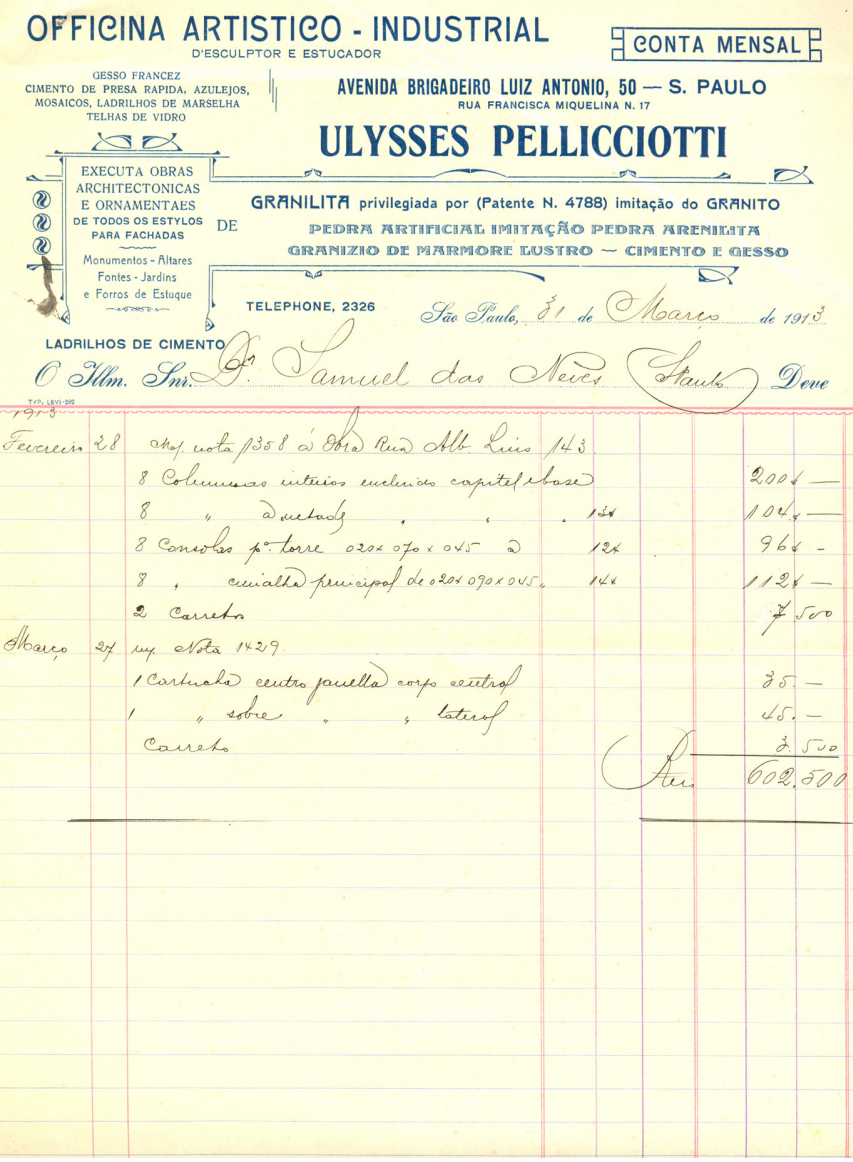



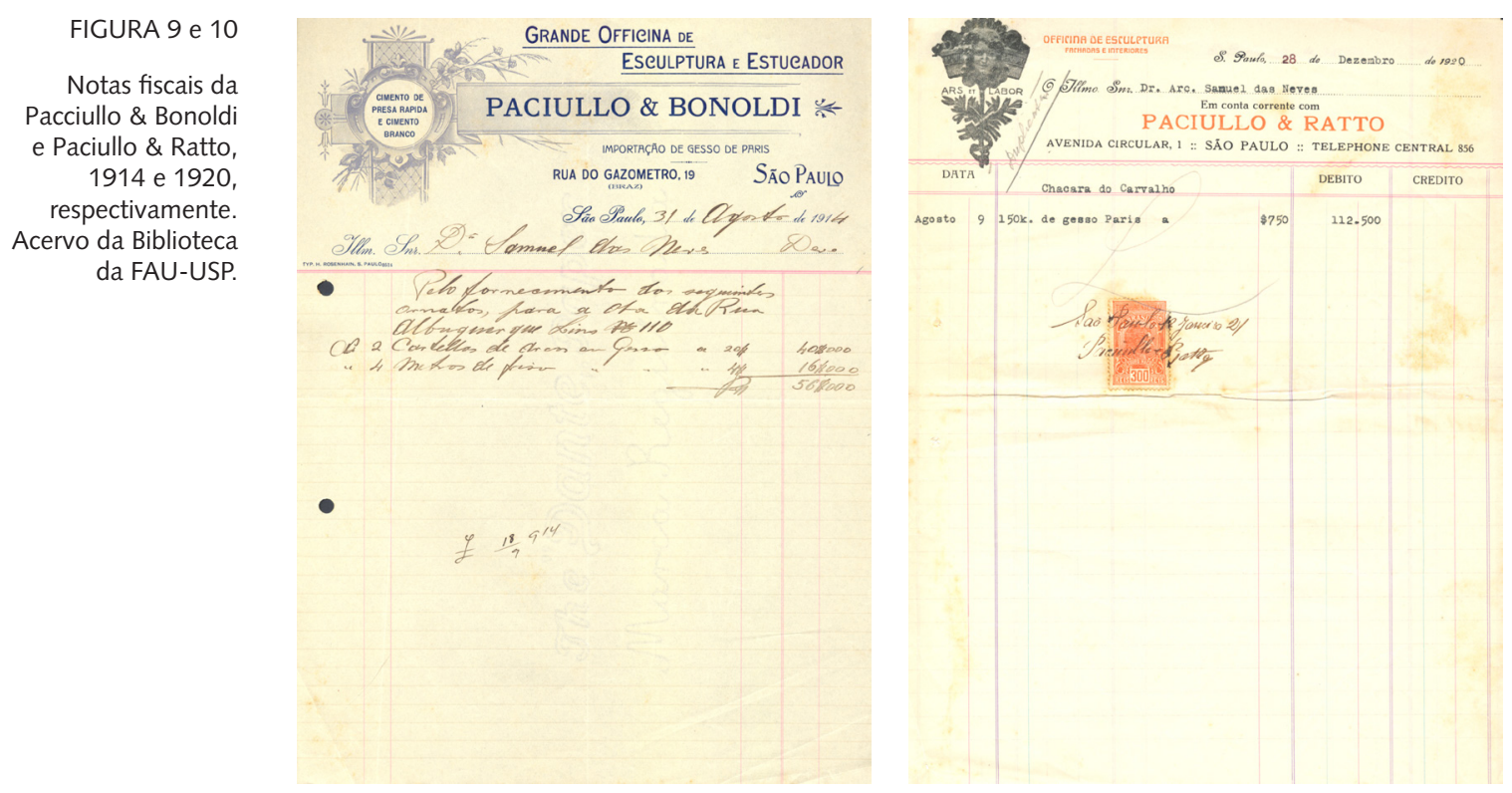

do ramo. Oferecia produtos variados para construção, como pisos e revestimentos, e ornamentação arquitetônica. Trabalhava com granito e estuques, sendo estabelecimento pioneiro na produção de elementos rochosos artificiais e no polimento mecânico de pedras. Ao lado da produção de materiais, tinha em seu quadro de funcionários uma série de profissionais extremamente capacitados. Atuaram em diversas obras importantes no período, como a Igreja de São Bento, o Teatro Municipal e o Palácio das Indústrias e em diversas residências.

Com a denominação alterada para S/A Decorações Edis, Ulisses Pellycciotti foi sucedido pelo filho, Horácio Pellicciotti. A Casa de Decorações Edis foi uma das últimas a encerrar as atividades, já nos anos 1970, devido à falta de mercado para os produtos produzidos (MACAMBIRA, 1995, p. 29).

Também chegaram até o presente informações da Paciullo \& Bonoldi - Grande Officina de Esculptura e Estucador. Em 1914, a empresa estava situada na rua do Gasômetro, 19, no Brás. Como as outras firmas que atuavam na área de ornamentação, atuavam igualmente como importadores de gesso Paris. Naquele mesmo ano, trabalharam ao menos para quatro obras do Escritório Técnico de Samuel das Neves fornecendo 
cimento colorido; ornatos para fachadas, peitoris e para forro; cornijas; rosetas; frisos e gesso. Há informações da atuação dos Paciullo já na década anterior, posto que Agnello Paciullo foi responsável pelos ornatos ao menos do hall central da Vila Penteado, atual FAU Maranhão (MOTTA, 2012, p. 28), projeto de Carlos Ekman (1866-1940).

Em 1920, com o nome da empresa alterado para Paciullo \& Ratto - Officina de Esculptura - fachadas e interiores - Arts et Labor, passa a operar na Avenida Circular, $1^{7}$. Nesta fase, forneceram gesso para a Chácara do Carvalho. Mais para o final daquele decênio, o modelador Agnello Paciullo passou a trabalhar na Casa Francesa, de Victor Isnard, situada na rua da Consolação. ${ }^{8}$

\subsection{Os básicos (ou nem tanto...)}

Segundo Barbuy, os primeiros a trabalharem com o comércio de materiais básicos na cidade foram os portugueses ou luso-brasileiros, diferentemente das importadoras - primeiramente na mão de alemães - e do trabalho de acabamento, prioritariamente na mão de italianos e descendentes. Porém, a partir do final do século XIX, os alemães também passaram a ter predominância nos armazéns desta categoria na cidade (2006, p. 153).

Havia todo um comércio de produtos básicos para construção mesmo no Triângulo Histórico (formado pelas ruas Direita, XV de Novembro e São Bento) e adjacências - dividindo espaço com as casas importadoras, prestadoras de serviços e outras tipologias de comércio -, o que corrobora com a informação do surto de construção na cidade, ao menos no período que antecedeu a Primeira Guerra Mundial. Para os depósitos e oficinas, a região do Brás era a preferida por causa da proximidade com os ramais férreos, das grandes áreas disponíveis e por possuir mão de obra abundante, conforme verificado.

Uma das poucas empresas aqui estudadas ainda existentes e em mãos da mesma família é a Casa da Bóia - Rizkallah Jorge. Fabricante de artefa-

7. Atual Avenida Senador Queiroz.

8. A Casa Francesa foi responsável por elementos em obras de Christiano Stockler das Neves, como a Estação Inicial da Estrada de Ferro Sorocabana, em São Paulo (1936), e o Hotel Quitandinha, em Petrópolis (1940) (MACAMBIRA, 1985, p. 29). Porém, na documentação existente na Biblioteca da FAU-USP, não há registros do trabalho desta empresa nas obras supramencionadas. 
tos de metal para encanamentos de água, gás e esgoto, foi estabelecimento pioneiro do gênero no país. Funcionava também como oficina mecânica, de fundição, tornearia e niquelação, tendo sido precursora na metalurgia. Seu fundador, Rizkallah Jorge Tahan (1869-1949), imigrou da Síria para São Paulo em 1895. Desde a chegada ao país, dedicou-se às atividades que já desenvolvia em sua terra natal mas que ainda eram inexistentes no Brasil: indústria metalúrgica, niquelação e fundição de chumbo e trabalhos com cobre.

A empresa foi inaugurada na Travessa do Brás em 1898, sendo em 1909 ampliada e transferida para a rua Florêncio de Abreu, onde se encontra até a atualidade. Com os lucros auferidos por sua empresa, Rizkallah Jorge aumentou sua indústria e passou a investir parte dos lucros em empreendimentos imobiliários, ao mesmo tempo em que também foi um grande filantropo (KORYBUT-WORONIECKI, 1954, p. 303). Reconhecida pela qualidade de seus produtos, a Casa da Bóia obteve o grande prêmio na Exposição Nacional de 1908 e medalha de ouro na Exposição Universal de Turim (1911).

FIGURA 11

Nota fiscal da Casa da Bóia referente a produtos para 0 edifício à rua Libero Badaró, 84-86, 1915. Acervo da Biblioteca da FAU-USP.

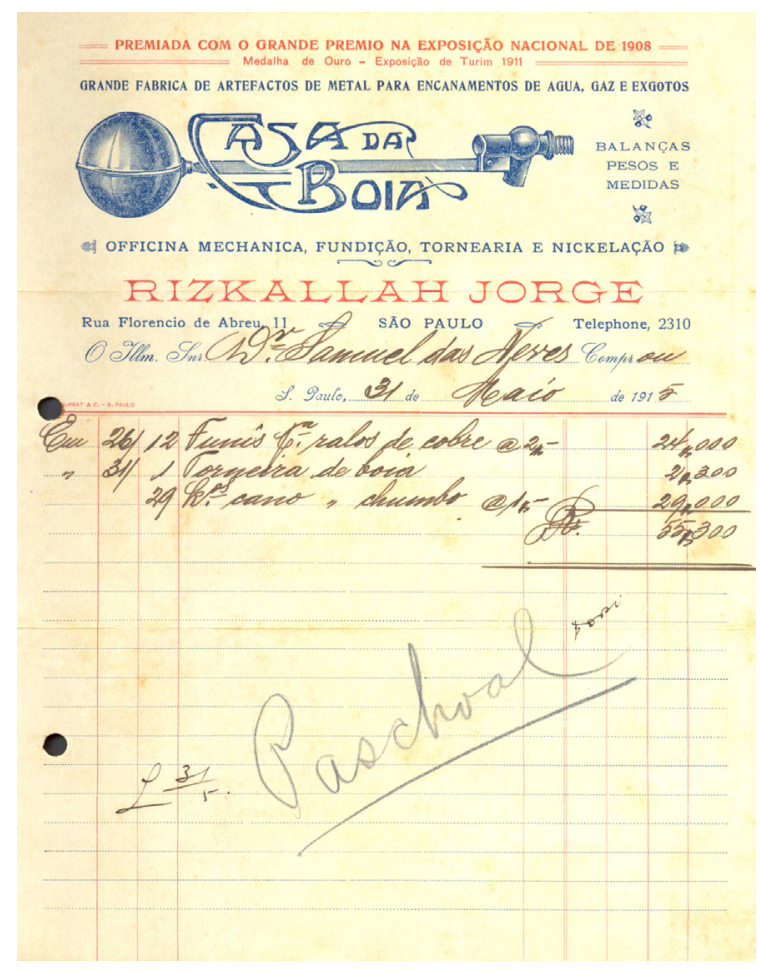


Também no segmento dos básicos, pode ser incluída a Casa Hermann, então situada na rua Direita, 9. Era especializada no fornecimento para sustentação das novas redes de eletricidade, água e gás encanado e esgotos. Inicialmente de propriedade de Hermann Theill, posteriormente passou para a viúva dele. Forneceram diversos materiais para as obras de Samuel das Neves, como junções, torneiras, filtros, latrinas, lavatórios, válvulas, mesas de mármore, lavatórios de mármore, pias, bidês, aquecedores, banheiras e fogões a gás.

Em relação ao fornecimento de materiais argilosos, o Estabelecimento Cerâmico Sacoman Frères foi o mais destacável, apesar da existência de inúmeras pequenas olarias ao longo do Rio Tietê. A fábrica Sacoman em muito ampliou o desenvolvimento da região em que se instalou, mais tarde dando nome ao próprio bairro.

Os irmãos Antoine, Henri e Ernest Sacoman eram originários de Marselha, onde seus ancestrais fabricavam a famosa telha plana de terracota - a telha de Marselha - que, a partir do final do século XIX, seria a substituta da telha de canal característica da arquitetura colonial brasileira. Chegaram a São Paulo por volta de 1886 com o propósito de fabricação das famigeradas telhas e de outros objetos em terracota. Imbuídos de tal intuito, fizeram tentativas de obtenção da argila apropriada e instalação da fábrica em vários locais, como a Água Branca e Osasco, malogrando as duas iniciativas porque não conseguiram a matéria-prima de que necessitavam.

A argila apropriada só foi localizada após diversas tentativas, por volta de 1890, nas proximidades do bairro do Ipiranga, na paragem denominada Moinho Velho. Em um primeiro momento, estabeleceram uma pequena fábrica na atual rua do Manifesto e, depois, uma maior na Vila Prudente. Progrediram então sob a denominação comercial Estabelecimento Cerâmico Sacoman Frères. Dado o conhecimento dos irmãos e a qualidade da argila, rapidamente as telhas produzidas passaram a disputar mercado com as francesas até em nível internacional. Em 1923, após o falecimento de Antoine (1923), os outros dois irmãos retornaram à França e venderam a empresa, que passou a ser denominada Cerâmica Sacoman S.A. (KORYBUT-WORONIECKI, 1954, p. 37-38; CORREIO DA MANHÃ, Rio de Janeiro, 21 ago. 1954, p. 44). 


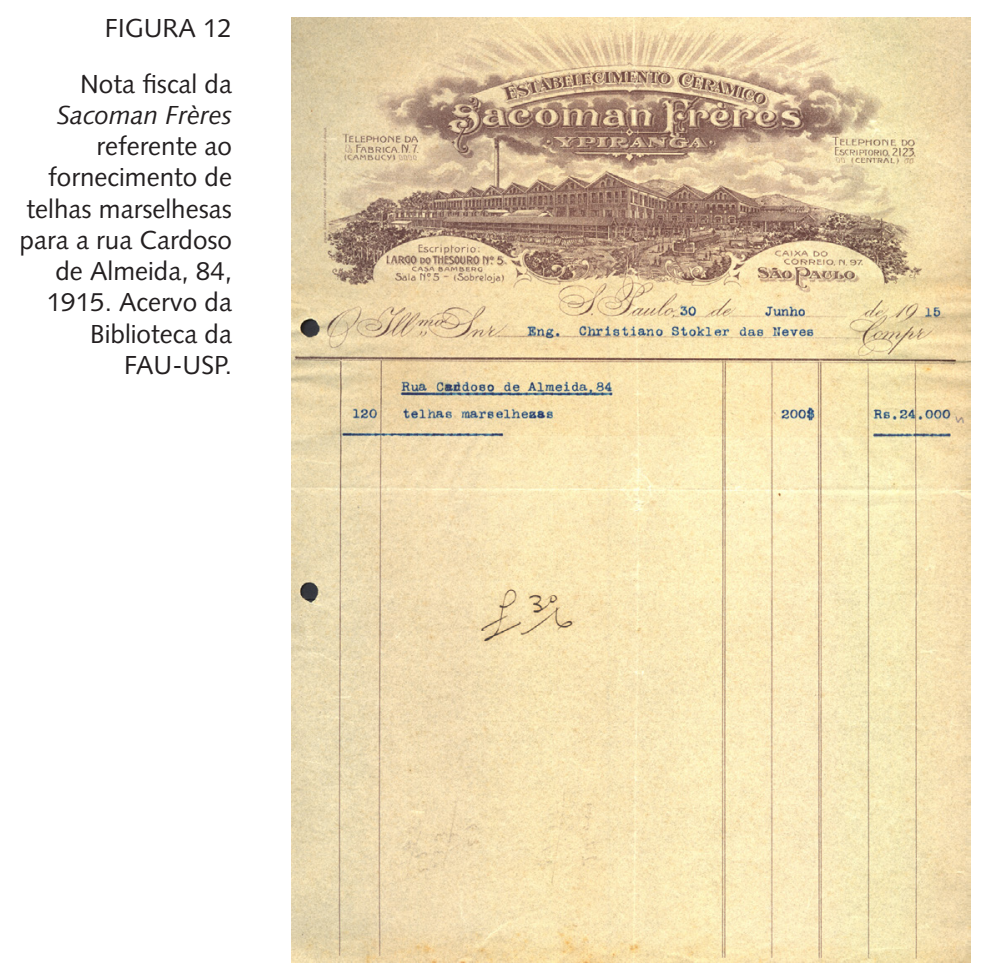

A qualidade dos produtos apresentava um grau de excelência tão grande que a Sacoman Frères foi um dos poucos fornecedores nacionais para a construção da Estação da Luz (1895-1902), e para outras tantas obras, para as quais forneceram tijolos, telhas Marselhesas e cumeeiras, entre outros produtos. A empresa encerrou as atividades em 1956.

Também no final do século XIX, em 1892, Francisco Amaro fundou o estabelecimento industrial Fundição do Braz, que passou em 1910 a ser propriedade de uma sociedade anônima organizada pelo próprio Amaro, sob a denominação de Companhia Metalúrgica e Importadora Paulista. Tinha o seu escritório comercial e técnico na rua Correia de Andrade, 20, no Brás, onde também funcionavam as vastas oficinas, divididas nas seções de fundição, mecânica, ferraria, caldeiraria, carpintaria e modelação. Fabricavam máquinas para a lavoura de café, arroz, cana e algodão, serras francesas e americanas; fundiam sinos e peças de ferro para construção e ornamentação de prédios, turbinas, comportas e tubos e produziam materiais para serviços sanitários, vagões para estrada de ferro, entre outros produtos. 


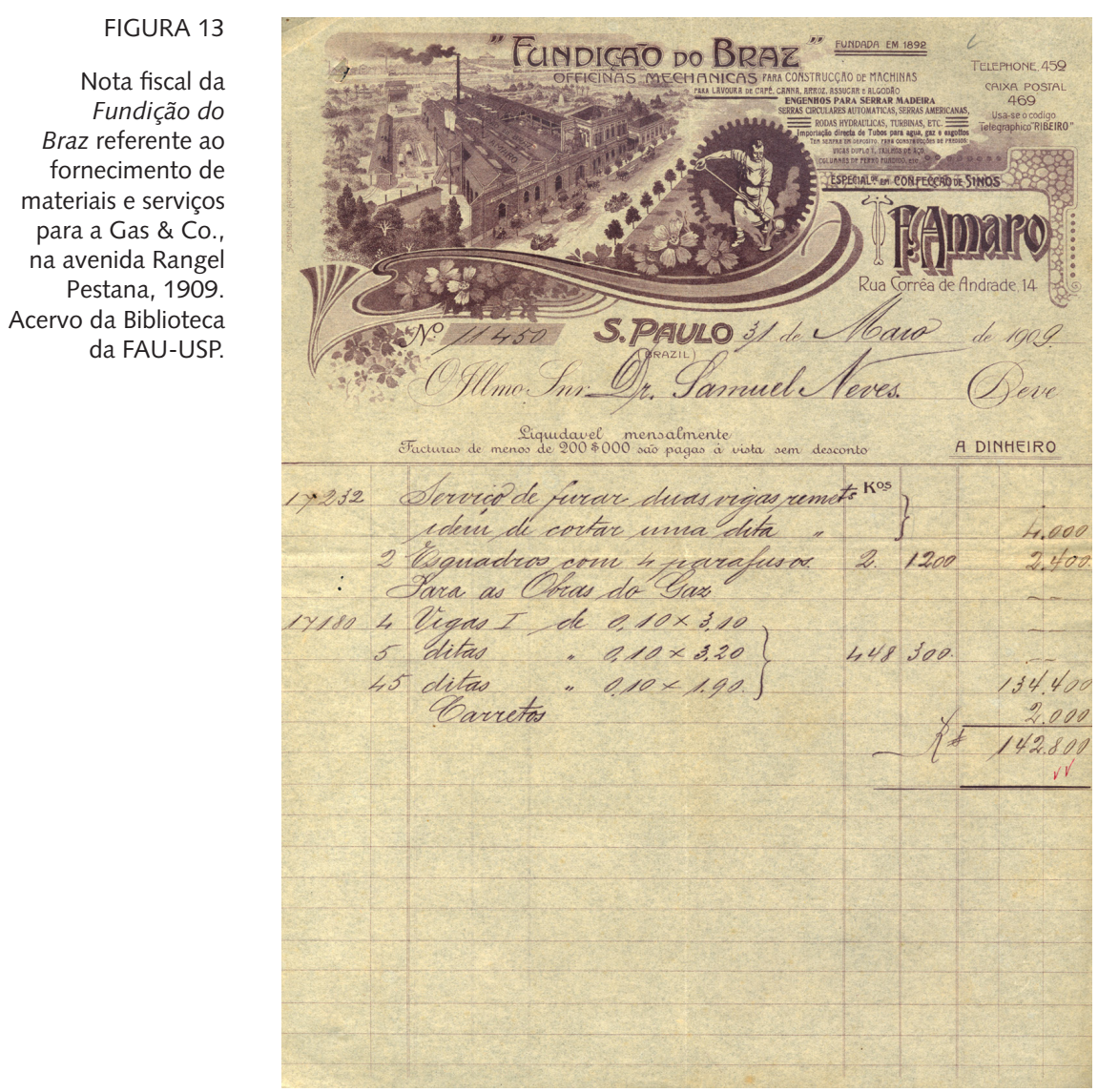

A Fundição Braz foi responsável pelas pontes e tubos condutores de água do rio Cabuçu para o Sistema Cantareira e também para o Guaraú; pela fachada artística do edifício do jornal Gazeta de Notícias, no Rio de Janeiro; pelas estruturas do Palacete Brícola ${ }^{9}$, do Hotel d'Oeste e do Teatro Colombo; pelas colunas artísticas do Teatro Municipal; além de produzir diversos elevadores, polias para a fábrica de tecidos Votorantim e material rodante para a linha férrea da Cantareira, em peças fundidas em ferro e em bronze (IMPRESSÕES, 1913). Também forneceram vigas para o edifício da Gas \& Co.

Outro empreendimento na mesma área era a Grande Fundição e Oficinas Mecânicas - Craig \& Martins. De Georg Craig e Jules Martin, a

9. Projeto de Samuel das Neves datado de 1904. 
Nota fiscal da Craig \& Martins referente ao fornecimento de materiais para obras do Conde de Prates, 1913. Acervo da Biblioteca da FAU-USP.

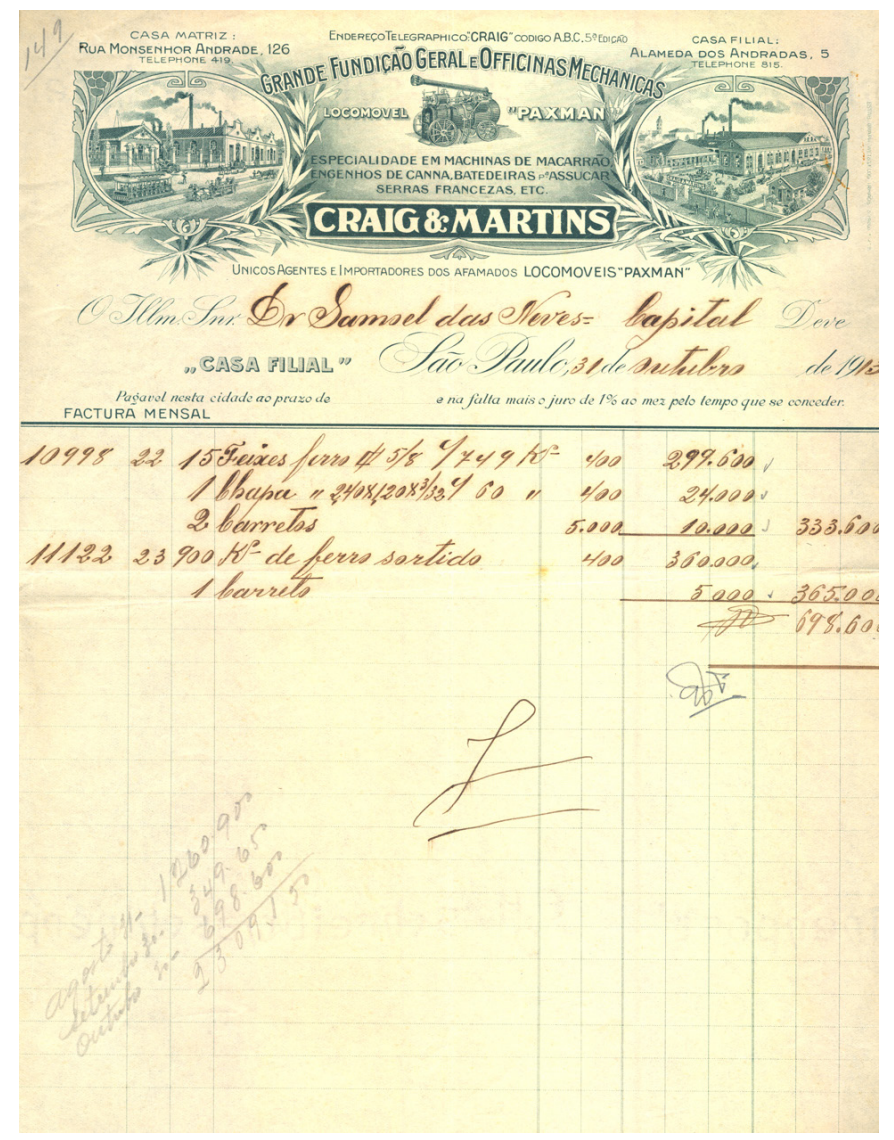

empresa fundada em 1895 tinha como endereço da matriz o número 126 da rua Monsenhor Andrade, no Brás e, como filial, o número 5 da rua dos Andradas, na região de Santa Ifigênia, já demonstrando o crescimento da atividade e, igualmente, a ampliação das atividades rumo a oeste. A casa era especializada na fundição de ferro e bronze, executando colunas de ferro, e em maquinário para a lavoura e para a indústria, produzindo máquinas de macarrão, para extração de caroço de algodão e para fabricação de papel; engenhos de cana e serras francesas, entre outros produtos.

Em 1914, a sociedade foi desfeita e cada sócio montou sua própria oficina, ficando Georg Craig com as instalações da matriz, no Brás. A partir de 1916, com o falecimento de Craig, ocorrrido no ano anterior, a razão social foi alterada para Grande Fundição Geral e Oficinas Mecânicas Viúva Craig \& Cia. (BELLUZZO, 1988, p. 461). Ainda na época da Craig 
\& Martins, forneceram para as obras de Samuel das Neves diversos elementos de ferro.

Como outras empresas do ramo, participaram da Exposição Universal de Milão (1906) e da Exposição Nacional do Rio de Janeiro (1908), obtendo grandes prêmios com uma máquina de fazer macarrão, a grande especialidade da oficina (BELLUZZO, 1988, p.461).

As serrarias constituem outro tipo de empreendimento fundamental para a construção civil. Destacam-se no conjunto a Krug \& Cia. Serraria São Carlos, Marcenaria e Carpintaria Ítalo-Americana - Pedro Sellaro, a Serraria Bella Vista e a Serraria e Serralheria Santa Lucia.

A Krug e Cia. - Serraria São Carlos foi fundada em 1904, pelo engenheiro Francisco Krug. Nos primeiros anos de funcionamento, explorou a Serraria São Carlos, na atual Avenida Rio Branco, em terrenos dos importadores e exportadores Prado, Chaves \& Cia. ${ }^{10}$, entre as linhas férreas da Sorocabana e da São Paulo Railway, atuando ainda como importadores, com desenvolvido comércio de madeiras nacionais e estrangeiras. A firma possuía vasta oficina de carpintaria, onde eram fabricadas portas, janelas e toda a sorte de obras de madeira para construção.

Em 1907, passam a representar diversas empresas de locomóveis, caldeiras, fábricas de máquinas para madeira e fabricantes de ferramentas e outros artigos de aço, todos de empresas da Alemanha, de onde era oriunda a família Krug. No começo de 1913, os sócios venderam a Serraria São Carlos, cujo escritório técnico passou a localizar-se no Largo São Bento, 6-A. Entraram então para esta seção da firma, como sócios solidários, os engenheiros Edmundo Krug ${ }^{11}$, Oscar Krug e David William Allen, e como sócio comanditário T. B. de Souza Carvalho.

Com a expansão dos negócios, passam a trabalhar com importações, exportações, comissões e consignações, possuindo depósitos de máquinas diversificadas. Ao lado destas atividades, possuíam ainda uma seção técnica encarregada da elaboração e execução de projetos de cons-

10. Empresa fundada em 1910 por proprietários de fazendas de café, primeiro como comissários e, depois, como exportadores.

11. Eduardo Krug colaborou com Samuel das Neves no primeiro projeto para a Fábrica de Calçados Clark, na Mooca, em 1908. 


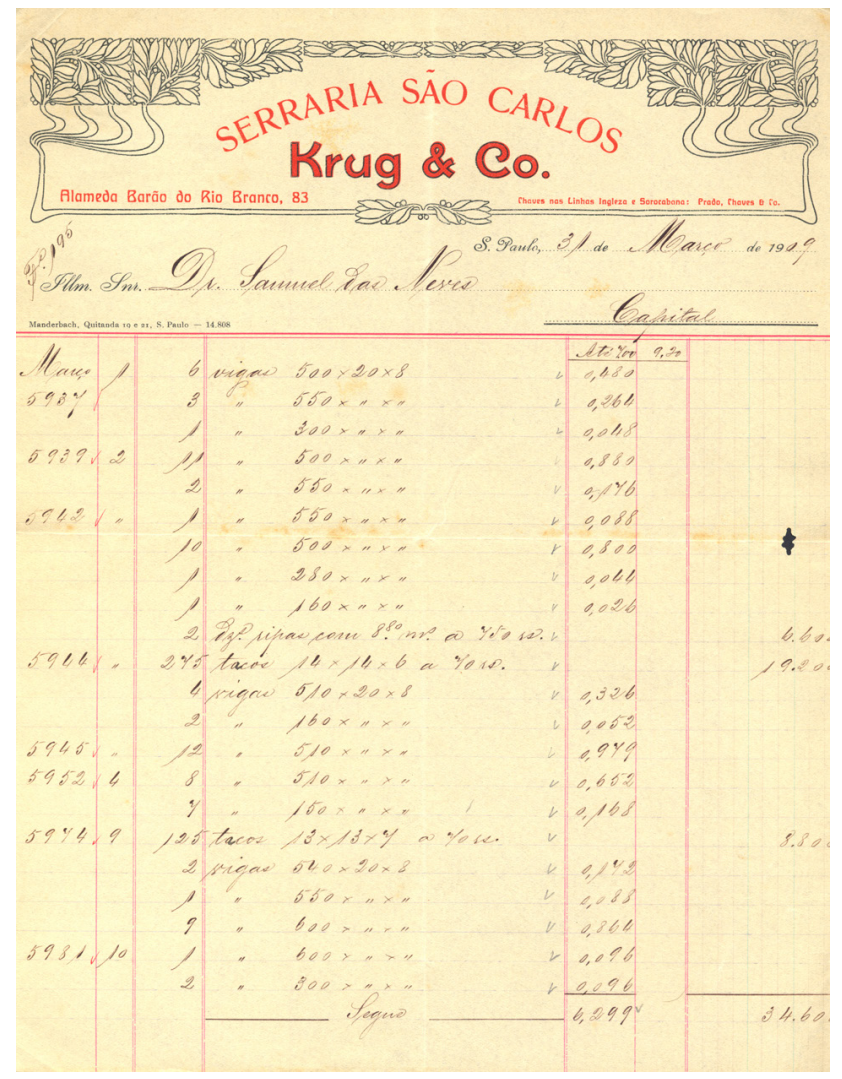

truções em geral, medições e levantamentos topográficos, construções de pontes, estradas de ferro e instalações de fábricas em geral (IMPRESSÕES, 1913). Forneceram vigas, tacos, ripas, colunas, tábuas, arquitraves, assoalho e forro para o edifício da Gas \& Co.

A Marcenaria e Carpintaria Ítalo-Americana - Pedro Sellaro trabalhava com madeira tanto em elementos estruturais como em portas e esquadrias, e ainda com vitrines e móveis, além de decorações completas. Desenvolveram trabalhos para o Teatro Municipal, em 1918 (BELLUZZO, 1988, p. 467), além de obras particulares, como algumas das realizadas pelo Escritório de Samuel das Neves.

Estabelecimento com semelhante importância foi a Serraria Bella Vista, propriedade de Ernesto Amadei. Funcionava como marcenaria e carpintaria a vapor no início da década de 1910 na rua Doutor Carvalho de Mendonça, 20, esquina com a rua Adolfo Gordo, 9, na Barra Funda. 
FIGURA 16

Nota fiscal da Marcenaria e Carpintaria ítaloAmericana - Pedro

Sellaro referente ao fornecimento de materiais para obra na rua Direita, 57

1915. Acervo da Biblioteca da FAU-USP.

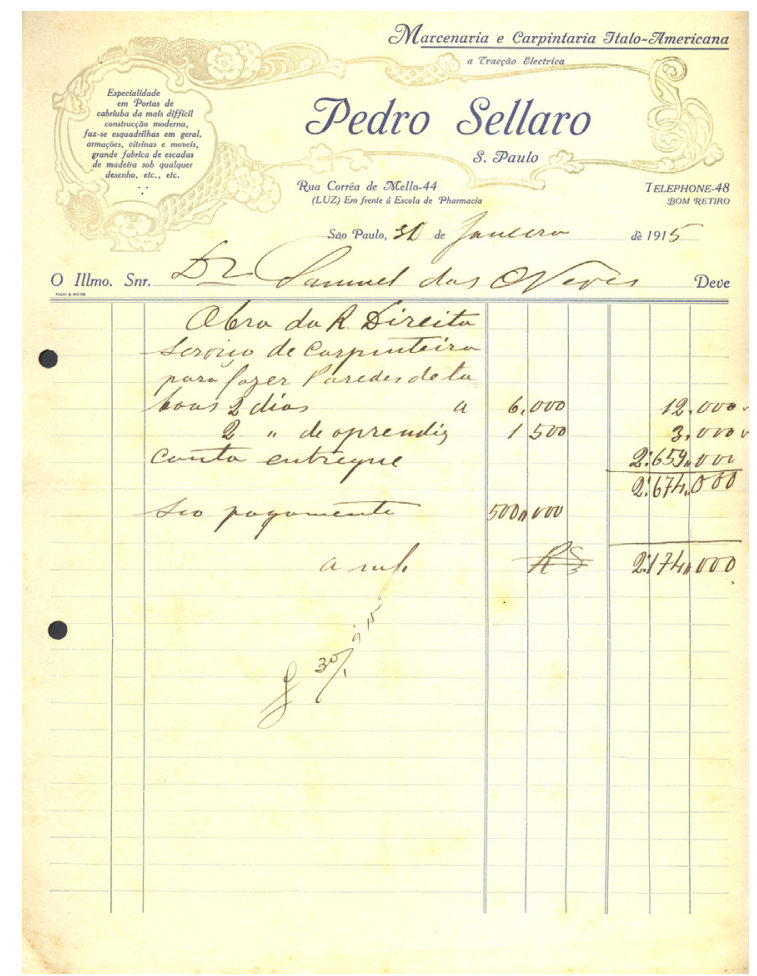

FIGURA 17

Nota fiscal da Serraria Bella Vista - Ernesto Amade \& Comp. referente ao fornecimento de materiais para obra na rua Albuquerque Lins, 1915. Acervo da Biblioteca da FAU-USP.

Serraria "BELLA VISTA" = Hareenaria e Carpintaria a Vapor =

Condmesto etmadei de Comple

Telephone, $525 \approx$ Rua Carvalho, $20 \ominus$ Rua Adolpho Gordo, $9 \approx$ S. PAULO

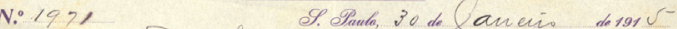

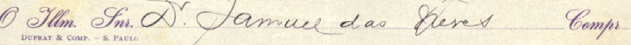

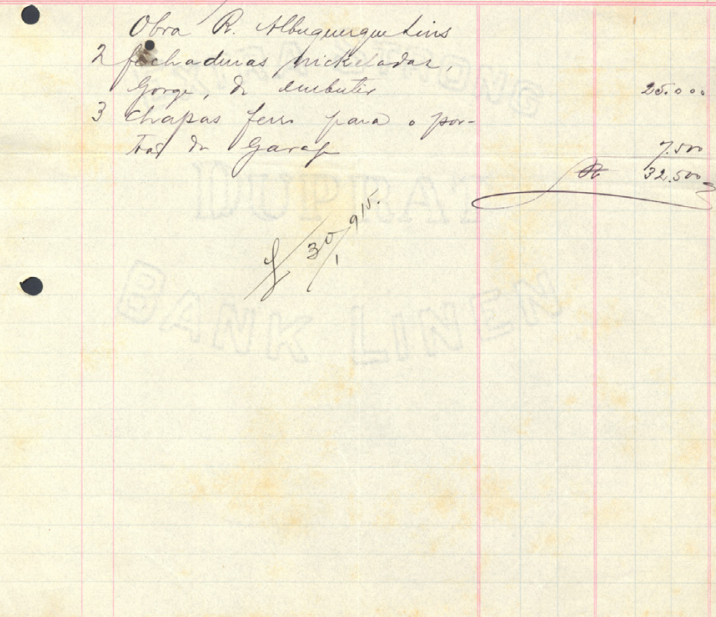


Fabricava principalmente portas, janelas e caixilhos. Também comercializava madeiras aparelhadas e brutas, nacionais e estrangeiras. A firma tinha como gerente José Facchini e como superintendente, o arquiteto de origem germânica Matheus Häussler (1852-?), também encarregado de realizar plantas e orçamentos para construções as mais diversas (PARETO JÚNIOR, 2011, p. 93). Como outras tantas empresas do período, forneceu material para o Teatro Municipal (BELLUZZO, 1988, p. 477) e para diversas construções de Samuel das Neves, de portas a parafusos.

Por fim, a Serraria e Serralheria Santa Lucia. Possivelmente, o estabelecimento pertencia a Rodolpho Aragão e ao engenheiro industrial cearense Regino Aragão. Situava-se na Avenida Antárctica, próximo ao Parque da Água Branca. Regino Aragão formou-se pela Escola Politécnica de São Paulo em 1900, iniciando a carreira como engenheiro-construtor. Foi o responsável pela construção do segundo teatro com o nome de São José na cidade - projeto de Carlos Ekman —, do qual posteriormente foi arrendatário, além de ter realizado inúmeras vilas operárias, residências e palacetes, na cidade de São Paulo, no interior e em outros estados.

Como outros tantos engenheiros do período, tinha outras fontes de renda além da construção e atuava em diversas ramos. Regino Aragão era

FIGURA 18

Nota fiscal da Serraria e Serralheria Santa Lucia referente ao fornecimento de materiais para o Palacete Sampaio Moreira, 1914 Acervo da Biblioteca da FAU-USP.

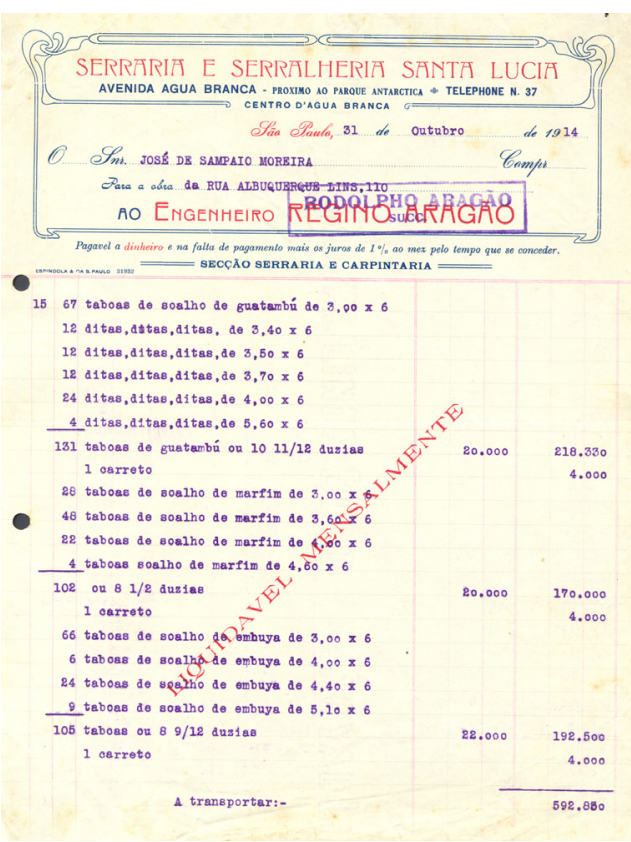


proprietário, além da Serraria e Serralheria Santa Lucia, de uma fábrica de ladrilhos, a Cruzeiro do Sul, na rua Vitalis, 44, em Carapicuíba. Era ainda vice-presidente da Brazilian Excursion Co. Ld., acionista da Companhia Garagens Reunidas e de outras sociedades anônimas, e concessionário dos serviços de água e esgotos de Santo Amaro, além de preparador de Química na Escola Politécnica de São Paulo desde o ano de sua formatura (IMPRESSÕES, 1913). Para o Palacete Sampaio Moreira, forneceu diversos tipos de tábuas de assoalho.

\section{CONSIDERAÇÕES FINAIS}

Certamente, as fontes ora utilizadas, apesar de serem incomuns e de sua riqueza intrínseca, só nos fornecem vestígios descontínuos. Apesar dessa limitação, foi possível verificar recorrências e o papel dos mesmos personagens em várias etapas da cadeia construtiva, como o próprio Samuel das Neves que, junto com membros da família, teve escritório de engenharia e empreiteira, depósito de material para construção - nacional e estrangeiro - e, como tantos capitalistas do período, investiu parte dos lucros auferidos na construção de imóveis para aluguel, além da atuação em outras empresas, sociedades anônimas e atividades paralelas. O sistema se repete para Ramos de Azevedo, Eduardo Krug e Regino Aragão, por exemplo.

Ainda que o Liceu de Artes e Ofícios e outras escolas profissionalizantes do período tivessem grande parte dos profissionais relacionados à construção e ornamentação em seus quadros técnicos, percebe-se pela amostragem acima a existência de diversos outros estabelecimentos de menor porte voltados para atividades congêneres e para outros segmentos fundamentais da construção civil. As casas de decoração e as pequenas oficinas foram escolas para muitos artesãos em São Paulo no início do século XX. Tiveram ainda uma grande importância para as construções da classe média e também para os pequenos proprietários quando tais estabelecimentos passaram a produzir ornamentos em série a um preço mais acessível do que os congêneres importados. No caso deste estudo, também serviram para produzir projetos modelados e fundidos para obras específicas a partir da encomenda de arquitetos e engenheiros para seus clientes.

A cidade de São Paulo conheceu novas tipologias habitacionais, técnicas construtivas e estilos arquitetônicos graças à importação de materiais 
e modelos, e à atuação do imigrante, cujo papel nas artes liberais e na construção civil é fator determinante, ao menos durante todo o período da República Velha. Há uma forte presença de estrangeiros, italianos, alemães, franceses, sírios e descendentes, mas muito pouco foi preservado sobre os estabelecimentos e profissionais, à exceção da Casa da Bóia, que ainda resiste em seu endereço na rua Florêncio de Abreu, possuindo até um museu com o intuito de preservar a memória do comércio e dos primórdios da industrialização em São Paulo, exemplo único no recorte estudado.

As empresas ora estudadas produziam elementos diversos, voltados para diferentes segmentos - agrícolas, de infraestrutura, urbanos e residenciais - , situando lojas em pontos estratégicos do centro e as oficinas e depósitos normalmente nos bairros operários, próximos às ferrovias e com grande contingente de mão de obra disponível. Em um meio eminentemente masculino, chama atenção a participação das viúvas de Hermann Theill e de Georg Craig, que assumem os negócios e passam a ser juridicamente responsáveis por eles.

Igualmente merece destaque o esmero de muitas das notas fiscais: com desenhos a bico de pena representando as fábricas, produtos ou mesmo decorações estilizadas, buscam sempre agregar valor aos produtos comercializados; daí a ênfase conferida às premiações nas exposições nacionais e internacionais, o que poderia propiciar maior credibilidade e demonstrar o grau de excelência par a par com os símiles estrangeiros.

De qualquer forma, o recorte e a documentação localizada não deixa de possuir limitações temporais, espaciais e, certamente, de ordem subjetiva. O material analisado, considerado normalmente sem valor e com suporte frágil, chegou até o presente de maneira incompleta. Foram apenas preservadas as notas de habitações ligadas a uma classe média ou abastada, de importantes personalidades. Todo o material referente a diversas vilas operárias, galpões para fábricas, residências mais modestas projetadas ou construídas pelo Escritório inexiste nesta documentação.

Enfim, todo conjunto documental analisado parte de uma escolha pessoal. Ele é fruto do grupo que o produziu. Portanto, não há a intenção de representar um todo a partir dele, mas expor como funcionavam algumas cadeias produtivas na construção civil paulista na período de estudo. 


\section{REFERÊNCIAS}

BARBUY, Heloisa. A cidade-exposição: comércio e cosmopolitismo em São Paulo, 1860-1914. São Paulo: Edusp, 2006.

BELLUZZO, Ana Maria de Moraes. Artesanato, arte e indústria. 1988. Tese (Doutorado em Arquitetura e Urbanismo ) - Faculdade de Arquitetura e Urbanismo, Universidade de São Paulo, São Paulo, 1988.

DANON, Diana Dorothèa; TOLEDO, Benedito Lima de. São Paulo: "Belle Époque". São Paulo: Companhia Editora Nacional/ Edusp, 1974.

ESPÍRITO SANTO, José Marcelo do. Palácio das Indústrias: estudo e re-apropriação de um espaço paulistano. 1987. Monografia (Trabalho de Graduação Interdisciplinar) - Faculdade de Arquitetura e Urbanismo, Universidade de São Paulo, São Paulo, 1987.

EXPOSIÇÃO. O Estado de S. Paulo, 28 out. 1916, p. 4.

IMPRESSÕES do Brazil no século XX. London e Rio de Janeiro: Lloyd’s Great Britain Publishing Comp. Ltd., 1913. Transcrição disponível em: <http://www.novomilenio.inf.br/santos/ h0300g39d.htm>. Acesso em: 27 mar. 2016.

KORYBUT-WORONIECKI, Jan (Org.). ...Eles construíram a grandeza de São Paulo: in memorian. São Paulo: Sociedade Brasileira de Expansão Comercial, 1954.

LEMOS, Carlos A. C. Alvenaria burguesa: breve história da arquitetura residencial de tijolos em São Paulo a partir do ciclo econômico liderado pelo café. 2 ed. [revista e ampliada]. São Paulo: Nobel, 1989.

Ramos de Azevedo e seu escritório. São Paulo: Pini, 1993.

MACAMBIRA, Yvoty de Macedo Pereira. Os italianos e a arquitetura paulistana. Revista de italianística, [S. 1.], v. 3, n. 3, p. 61-72, dec. 1995. ISSN 2238-8281. Disponível em: <http://www. revistas.usp.br/italianistica/article/view/87845>. Acesso em: 29 fev. 2016.

Os mestres da fachada: artistas-artesãos. São Paulo: CCSP, 1985.

MELLO, Regina Lara Silveira. Casa Conrado: cem anos de vitral brasileiro. 1996 210F. Dissertação (Mestrado em artes) - Instituto de Artes, Unicamp, Campinas, 1996.

MOTTA, Flávio L. São Paulo e o art nouveau. In: MARTINS, Maria Lucia Refinetti Rodrigues (Org.). Vila Penteado 1902-2012: pós graduação 40 anos. São Paulo: FAU-USP, 2012, p. 23-9.

NASCIMENTO, Ana Paula. Espaços e a representação de uma nova cidade: São Paulo (18951939). 2009. Tese (Doutorado História e Fundamentos da Arquitetura e do Urbanismo) - Faculdade de Arquitetura e Urbanismo, Universidade de São Paulo, São Paulo, 2009.

OS IRMÃOS Sacoman. Correio da Manhã, Rio de Janeiro, 21 ago. 1954, p. 44.

PARETO JÚNIOR, Lindener. O cotidiano em construção: os "práticos licenciados" em São Paulo (1893-1933). 2011. Dissertação (Mestrado em História e Fundamentos da Arquitetura e do Urbanismo) - Faculdade de Arquitetura e Urbanismo, Universidade de São Paulo, São Paulo, 2011. 


\section{ACERVOS CONSULTADOS}

Acervo da Biblioteca da Faculdade de Arquitetura e Urbanismo da Universidade de São Paulo. Fundo Samuel Augusto das Neves - Seção de Materiais Iconográficos.

Acervo digital do jornal O Estado de S. Paulo. Disponível em: < http://acervo.estadao.com.br>.

Artigo recebido em: 13/3/2017

Artigo aprovado em: 03/7/2017 